Gönderim Tarihi: 26.03.2018 Kabul Tarihi: 29.08.2018

\title{
BANKALARDAKİ KURUMSAL SOSYAL SORUMLULUK FAALIYETLERININ MARKA DEĞERİ ALGISINA ETKISİ: BİR ALAN ARAŞTIRMASI
}

\author{
Nurettin PARILTI* \\ Illknur CAN ${ }^{* *}$ \\ Sait BARDAKÇI $I^{* * *}$

\section{THE IMPACT OF CORPORATE SOCIAL \\ RESPONSIBILITY ACTIVITIES ON THE BRAND VALUE PERCEPTION OF THE BANK: A FIELD SURVEY}

Öz

Günümüzde gelişen pazarlama stratejileriyle birlikte kurumların gerçekleştirdiği sosyal sorumluluk faaliyetlerinin marka değeri algısı üzerindeki etkisi önem kazanmıştır. Çalışmada kurumsal sosyal sorumluluk (KSS) faaliyetlerinin marka değeri algısı üzerinde yarattığı etkiler incelenmektedir. $\mathrm{Bu}$ çerçevede Cumhuriyet Üniversitesi ve Gazi Üniversitesi Bankacılık bölümü öğrencilerinin kurumsal sosyal sorumluluğa verdikleri önem ve üniversitelerinin anlaşmalı oldukları bankalarının sosyal sorumluluk faaliyetlerinin marka değeri algılarına etkisi ölçülmek istenmektedir. Bu amaçla 353 üniversite öğrencisine yüz yüze anket çalışması uygulanmış ve anketler kontrol edildikten sonra analize uygun görülenler değerlendirilmiştir. Anket verilerinin analizinde frekans dağılımları, güvenilirlik analizi, t-testi, ANOVA testi ve regresyon analizi yapılmıştır. Yapılan analizler neticesinde üniversite öğrencilerinin demografik değişkenlerden cinsiyet, hane geliri ve üniversite farkının hizmet aldıkları bankaların KSS projelerini algılamalarında etkili olmadığı sonucuna ulaşılmıştır. Ayrıca öğrencilerin genel marka değeri algısı ile marka farkındalığı değerleri cinsiyete göre anlamlı bir farklılık göstermezken marka sadakatleri ve algılanan kalite değerleri anlamlı bir farklılık göstermektedir. Korelasyon ve regresyon analizi sonuçlarına göre öğrencilerin algıladıkları KSS düzeyleri arttıkça marka değeri algıları da olumlu yönde artmaktadır.

Anahtar Kelimeler: Sosyal Sorumluluk, Kurumsal Sosyal Sorumluluk, Marka Değeri Algısı.

\footnotetext{
* Prof. Dr., Türk Hava Kurumu Üniversitesi, İşletme Fakültesi, e-posta: parilti@thk.edu.tr.

** Arş. Gör., Sivas Cumhuriyet Üniversitesi, İİBF, Bankacıllk ve Finans Bölümü, e-posta: ilknurcan@cumhuriyet.edu.tr.

*** Arş. Gör. Dr., Sivas Cumhuriyet Üniversitesi, İIBF, İşletme Bölümü, eposta: sbardakci@cumhuriyet.edu.tr.
} 


\begin{abstract}
Today, with the developing marketing strategies, the effect of the social responsibility activities realized by the institutions on the brand perceived value has gained importance. The effects of corporate social responsibility (CSR) activities on brand value perception are examined in the study. In this context, the importance of the students of Cumhuriyet University and Gazi University Banking Department to the corporate social responsibility and the effect of the universities on the brand value perceptions of the social responsibility activities of the banks to which they are contracted are desired to be measured. For this purpose, a face-to-face questionnaire was applied to 353 university students and after the questionnaires were checked, the ones considered suitable for analysis were evaluated. Frequency distributions, reliability analysis, t-test, ANOVA test and regression analysis were performed in the analysis of questionnaire data. As a result of the analyzes made, it was concluded that university students' demographic variables, gender, household income, and university discrimination were not effective in perceiving the CSR projects of the banks they served. In addition, brand loyalty and perceived quality values show a meaningful difference while the general brand sense of students and brand awareness values do not show any significant difference according to gender. According to the results of correlation and regression analysis, as the CSR levels perceived by the students increase, brand value perceptions also increase positively.
\end{abstract}

Keywords: Social Responsibility, Corporate Social Responsibility, Brand Value Perception.

\title{
1.Giriş
}

Dünyada gerçekleşen hızlı küreselleşmeyle birlikte bilgi ve iletişim teknolojilerinin gelişmesi de hız kazanmıştır. Bu hızlı değişim karşısında işletmeler rollerini tekrar gözden geçirmek zorunda kalmaktadırlar. Bahsedilen yeniliklerle beraber firmalar ürün veya hizmet sunmanın yanı sıra toplumun çıkarlarını koruma ve topluma pozitif katkı sunma, çevre ve insan hakları konularında aktif rol almak zorunda kalmışlardır. Üstlendikleri bu yeni sorumluluklar "sosyal sorumluluklar" şeklinde tanımlanmaktadır (Alparslan ve Aygün 2013:436). Sosyal sorumluluk kavrami; işletmenin ekonomik faaliyetlerini yürütürken toplum çıkarlarına zarar vermeden yönetmesi işlemi olarak ifade edilmektedir. Kısacası firmaların ekonomik ve sosyal koşullara, iş etiğine, işletme içi ve dışı grupların beklentilerine uygun çalışmasıdır (Diken ve Çelebi 2015:235).

Firmalar sosyal sorumluluk faaliyetleri ile müşterilerinin ve potansiyel müşterilerinin sempatilerini kazanmakta ve böylece kurumsal imajlarını artırmaktadırlar. Ayrica kurumsal sosyal sorumluluk faaliyetleri, markanın farkındalığı ve tercih edilebilirliği konusunda olumlu katkılar 
sunmaktadır. Kurumsal sosyal sorumluluk faaliyetinde bulunan firmalar sattıkları her bir üründen kazanılan gelirin belirli bir miktarını sosyal sorumluluk projesine aktardığını duyurmaktadırlar. Böylece tüketiciler sosyal sorumluluk faaliyetlerinde bulunan firmalara olumlu açıdan yaklaşmakta ve tercihlerinde öncelik vermektedirler. Böylelikle firmalar belirli ölçüde marka sadakati oluşturabilmektedir (Çakır ve Arslan 2016:438).

Sınırsız tüketici ihtiyaçlarını karşılamaya çalışan firmalar bir de artan rekabet ortamında ayakta kalabilmek için sosyal sorumluluk faaliyetlerini de yürütmeye başlamışlardır. Artan rekabet ortamı, mevcut müşteri kitlesinin potansiyel müşteri kitlesinden daha değerli olduğunu firmalara göstermiştir. Bu yüzden firmalar marka sadakati algısını yüksek tutmak istemektedirler. Müşteriler kendi istekleri karşılandiktan sonra diğer bireylerin de olumlu şartlarda yaşam standardında olmasını isterler. Burada sosyal sorumluluk faaliyetleri önem kazanmaktadır. Müşteri açısından hem sosyal sorumluluk faaliyetlerine önem veren hem de müşterilerinin isteklerini karşılamada yeterli olduğu düşünülen firmaların daha çok tercih edildiği tahmin edilmektedir. Bu beklentiden yola çıarak çalışmada bankaların yaptıkları kurumsal sosyal sorumluluk faaliyetlerinin müşterilerin marka değeri algılarında etkili olup olmadığının belirlenmesi amaçlanmıştır. Çalışmada çalışma grubu olarak üniversite öğrencilerinin tercih edilmesinin nedeni öğrencilerin tüketici, müssteri ve aynı zamanda geleceğin yönetici pozisyonunda olacağı beklentisidir (Gonzalez-Rodriguez vd. 2013:2362).

KSS algısını iki farklı şekilde ölçmek mümkündür. Bunlardan ilki çalışanların kurumlarının sosyal sorumluluk faaliyetleri hakkındaki algılarına yöneliktir. İkincisi ise tüketicilerin kurumların gerçekleştirdikleri sosyal sorumluluk faaliyetlerini algılama biçimleridir. Özellikle üniversite öğrencilerinin KSS algı düzeylerinin analiz edilmesi uluslararası literatürde önem arz eden konulardan biridir (Anbar vd. 2017:123). Bundan dolayı öğrencilerin bankalarda KSS algılarının değerlendirilmesi önem arz etmektedir. Ülkemizde üniversite öğrencilerinin bankalarda KSS algısı ve marka değeri algısını ölçen çalışmalar sınırlı sayıdadır. Bu sebeple bu çalışmanın Türkçe literatüre olumlu katkısı olacağı düşünülmektedir.

\section{Literatür}

\subsection{Kurumsal Sosyal Sorumluluk (KSS)}

İş dünyasında sorumluluğun önemi günümüzde yaygın bir şekilde kabul edilmektedir (Lamsa vd. 2008:45) Az sayıda insan ise modern kültürün 
sosyal, politik, ekonomik ve diğer yönlerinde meydana gelen önemli değişimleri inkar etmektedir. $\mathrm{Bu}$ değişimlerin bazıları iş adamları tarafindan sevilebilir ya da sevilmeyebilir; fakat her ne olursa olsun değişimler vardır ve yüzleşilmek zorundadır. Toplumdaki kültürel değişimlerin yöneticiler tarafından izlenmesi gerekmektedir. Bu yüzden yöneticilerin aldıkları kararlarda sosyal sorumluluk kavramı dikkate değer bir konu haline gelmiştir (Davis 1960:70). Kavramsal olarak sosyal sorumluluk; ekonomik, teknolojik ve sosyal yeniliklerle birlikte zamanla değişmekte ve gelişmektedir (Anbar vd. 2017:121). Kurumsal sosyal sorumluluk kavramı oldukça subjektiftir. Bundan dolayıdır ki evrensel kabul edilen bir tanımı bulunmamaktadır (Jones, Comfort ve Hillier 2007:583).

Kurumsal sosyal sorumluluk kavramı 1930'lu yıllardan bu yana bahsedilen konulardan biridir ve Wendell Wilkie tarafindan dile getirilmiştir. Bununla birlikte konuyla ilgili ilk kitap olduğu tahmin edilen çalışma 1953 yılında "İş Adamının Sosyal Sorumlulukları" (Social Responsibilities of the Businessman) Howard R. Bowen tarafindan yayınlanmıştır. 1950'lerin ortalarında işletmelerin toplumsal sorumlulukları üzerine tartışmalar yaygınlaşmıştır. Sosyal sorumluluk tanımına dair ortak bir kanı olmamakla birlikte 1960 yılında Keith Davis, iş adamlarının aldıkları kararlar ve uygulamalarında kısmen de olsa firmanın, ekonomik veya teknik ilgilerinin ötesinde nedenlerle de ilgilendiklerini ileri sürmüştür (Carroll 1979:497). Milton Friedman 1962 yılında sosyal sorumluluk prensibini kaçınılmaz bir güç olarak ifade etmektedir. Friedman'a göre artık toplum için şirket yöneticileri ve hissedarların daha fazla para kazanmasından başka sosyal sorumluluk faaliyetinde de bulunmaları önem arz etmektedir (Friedman 1962:112).

KSS işletmelerin sürdürülebilir kalkınmaları açısından önem arz etmektedir (Anbar vd. 2017:122). Kurumsal sosyal sorumluluk faaliyeti yürütürken temel amaç, işletme kârlılığını olumlu yönde artırmaya çalışırken diğer bütün paydaşlara karşı da sorumlu davranmaya çalışmaktır (Altunoğlu ve Saraçoğlu 2013:70).

Moon (2007), kurumsal sosyal sorumluluğun sürdürülebilir kalkınmaya etkisini araştırmıştır. Buna göre; kurumsal sosyal sorumluluk sürdürebilir kalkınma ile kıyaslanmaktadır. Piyasaların genişlemesi ve küreselleşme ile birlikte son zamanlarda kurumsal sosyal sorumluluğun artış eğilimi gösterdiği ifade edilmektedir. Sürdürülebilir kalkınma için KSS'nin bir araç olduğu ve bazı kısıtlamalar bulunduğundan bahsedilmektedir.

Cingöz ve Akdoğan (2012), Kayseri OSB'de faaliyet gösteren işletmelerin KSS algı düzeylerini ölçmüşlerdir. Buna göre yöneticiler 
işletmelerinde KSS faaliyetlerinin alt boyutlarıyla birlikte gerçekleştiğini düşünmektedirler.

Son yıllarda ekonomik faaliyetlerin sosyal etkisi şirket yöneticileri tarafindan dikkat edilen bir olgudur (Gonzalez-Rodriguez vd. 2013:2361). Fakat firmalar tarafindan yürütülen KSS faaliyetlerine toplumun değer yapısını dâhil eden çalışmalar yeterli değildir. $\mathrm{Bu}$ eksiklik, yükseköğretim kurumlarında da gözlenmektedir (Weber vd. 2004:360). Gonzalez-Rodriguez vd. (2013), üniversite öğrencilerinin KSS algılarını ölçmüşlerdir. Öğrencilerin değer yargılarının bu algıyı nasıl etkilediğini analiz etmişlerdir. 2011-2012 yılları arasında İspanya, Bulgaristan ve Polonya olmak üzere üç farklı ülkeden ve üç farklı üniversite öğrencilerinin dâhil edildiği bir çalışma yürütmüşlerdir. Buna göre KSS algısının; cinsiyet, uyruk ve tutumlara göre değişmekte olduğu yönünde bulgular elde edilmiştir.

Alparslan ve Aygün (2013), Borsa İstanbul (BİST)'a kayıtlı 177 firma verileri ile KSS ve performans düzeylerini incelemişlerdir. Sonuç olarak KSS ve firma performansı arasında pozitif bir ilişki olduğu sonucuna ulaşmışlardır.

Altunoğlu ve Saraçoğlu (2013), bir tatil beldesinde 6 otelin müşterilerine KSS uygulamalarının müşteri güveni, marka sadakati ve marka imajı etkisini araştırmışlardır. Buna göre; KSS faaliyetlerinin müşteri güveni, marka sadakati ve marka imajını artırdığı belirlenmiştir.

Tuzcu (2014), KSS faaliyetlerinin TÜPRAŞ çalışanlarının örgütsel bağl1lık ve iş tatminine etkilerini ölçmüştür. Sonuç olarak; çalışanların KSS algıları ile örgütsel bağlılıkları ve iş tatminleri arasında anlamlı bir farklılık bulunamamıştır.

Akkoyunlu ve Kalyoncuoğlu (2014), işletmeler tarafindan uygulanan KSS uygulamalarının marka algısı üzerindeki etkisini ölçmüşlerdir. Buna göre KSS faaliyetlerinin marka algısını etkilediği tespit edilmiştir.

Deneçli (2015), KSS faaliyetlerinin marka farkındalığına etkisini analiz etmiştir. Buna göre KSS faaliyetlerinden haberdar olan tüketicilerin marka farkındalığı anlamlı düzeyde daha yüksek çıkmıştır. Çakır ve Arslan (2016) ise kurumlar tarafından gerçekleștirilen sosyal sorumluluk faaliyetlerinin otomobil sektöründe marka sadakatine etkisini analiz etmişlerdir. Bu çalışmaya göre; aynı marka otomobili kullanan bireylerin marka sadakati algıları KSS faaliyetleri ile etkilenmektedir.

Anbar vd. (2017), üniversite öğrencilerin KSS algılama düzeyleri ile demografik değişkenler arasındaki ilişkiyi analiz etmişlerdir. Buna göre; sadece yaş değişkeni ile öğrencilerin KSS algı düzeyleri arasında anlamlı 
bir fark tespit etmişlerdir. Son olarak Söylemez ve Kayabaşı (2017), müşteri sadakati ve KSS faaliyetleri arasındaki ilişkiyi inceledikleri çalışmalarında müşteri sadakati ve KSS ilişkisinde kurum imajının tam aracılık etkisi olduğunu tespit etmişlerdir.

\subsubsection{KSS Alt Boyutları}

Carroll (1979,1991), kurumsal sosyal sorumluluğu dört alt boyutta göstermiş ve bunları piramit şekliyle sunmuştur. Carroll (1979,1991)'a göre KSS; ekonomik, yasal, etik ve gönüllü şeklinde dört alt boyuttan oluşmaktadır. $\mathrm{Bu}$ dört temel alt boyut işletmelerin toplumsal sorumluluklarını kapsamlı bir şekilde kategorize etmektedir. İş dünyasının temel sorumluluklarından biri ekonomik sorumluluktur. İşletmeler toplumun temel ekonomik birimidir. Bundan dolayı toplumun ihtiyacı olan mal ve hizmetleri sunma ve kâr elde etme sorumluluğu vardır. Diğer gerçekleştirilen faaliyetler bu temel varsayım üzerine kurulmuştur. Yasal sorumluluklar, işletmelerin üretim aşamasında gerekli hukuki sorumluluklarını yerine getirmesidir. Toplum, işletmelerden yasal sorumluluklarını yerine getirmesini beklemektedir. Her ne kadar ilk iki sorumluluk etik sorumluluğa dâhil olsa da bunlara ilave davranışlar ve faaliyetler vardır. Etik sorumluluklar resmi olarak bulunmaz fakat toplum tarafindan kabul edilen sorumluluklardır. Toplumdan topluma değişmekle birlikte toplumun yasal gerekliliklerinin üzerinde iş beklentileridir. Gönüllü sorumluluklar ise toplum tarafindan beklenmeyen, kurumların istekleri doğrultusunda yerine getirdikleri sorumluluklardır. $\mathrm{Bu}$ faaliyetleri uygulamak işletmelerin yasal zorunluluğu değildir. Kurumsal sosyal girişimler, promosyonlar, kurumsal hayırseverlik gibi uygulamalar bu faaliyetlere örnek olarak verilebilir.

Schwartz ve Carroll (2003), 1979 yılında oluşturulan KSS piramidini güncellemişlerdir. Buna göre hayırseverlik boyutu hem diğer boyutlarda hem de ahlaki boyutların içine dâhil edildiğinden dolayı yeni modelde yer verilmemiştir. Yeni modelin sunulmasının nedenlerinden biri piramidin yanlış yorumlanmaya açık olmasıdır. En alt seviyeden en üst seviyeye gidildikçe önem derecesinin değişeceği düşüncesi yanlıştır. Piramidin tabanı en düşük aşamayı ifade etmemektedir. Piramit çerçevesi dört alt boyutun önceliklerinin yanlış anlaşılmasına yol açabilmektedir. Ayrıca Carroll gönüllü veya isteğe bağlı yapılan faaliyetleri sorumluluk olarak kabul etmenin hatalı olacağını savunmaktadır. Yeni modelde gönüllü sorumluluklar ekonomik ve/veya ticari sorumluluklara dahil edilebileceği ileri sürülmektedir. Çünkü gönüllü faaliyetleri etik faaliyetlerden ayırt 
etmek zordur ve gönüllü faaliyetler ekonomik çıarlara dayandırılabilir. Şekil 1'e göre sorumlulukların birbiriyle örtüştüğü alanlar bulunmaktadır.

Şekil 1: Üç Boyutlu KSS Modeli

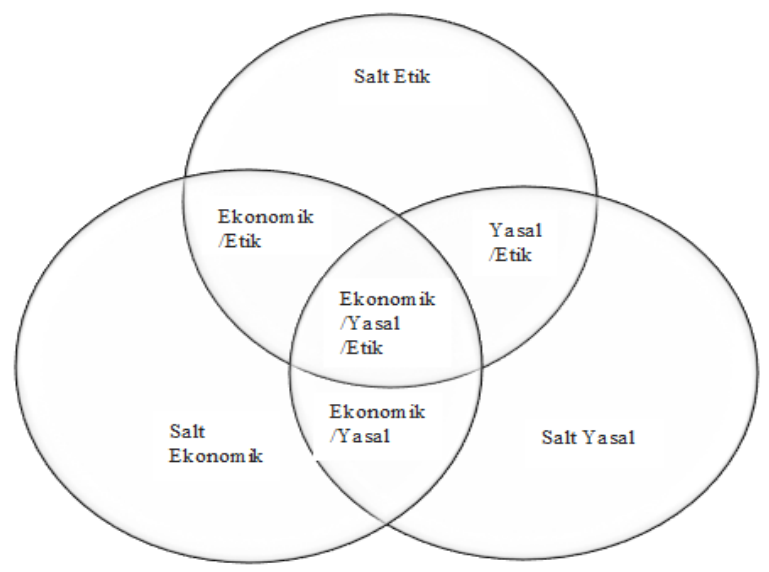

Kaynak: Schwartz ve Carroll, 2003:509.

$\mathrm{Bu}$ çalışmada Carroll'un güncel makalesi ve Singh vd. (2008) çalışmalarından yola çıkılarak KSS alt boyutları ekonomik/ticari, etik ve sosyal sorumluluk olmak üzere üç boyutlu analiz edilmektedir.

\subsection{Marka Değeri Algısı}

Marka, bir üreticinin ürünlerini diğerlerinden ayırmak için kullandığı bir araç olarak tanımlanmaktadır. Dünyada pazarlama kavramının önemli temsilcilerinden Amerikan Pazarlama Birliği-APB (American Marketing Association)'ne göre marka, bir satıcı veya satıcı grubunun mal ve hizmetlerini tanımlamayı ve ayırt etmeyi amaçlayan bir ad, terim, işaret, sembol ya da tasarım yahut bunların kombinasyonu olarak tanımlanmaktadır (Keller 2013:2). Bir başka tanıma göre marka; üretici veya satıcı firmanın ürünlerinin tanınırlığını sağlayan kimliği ve rakip ürünlerden ayırt edilebilmesini sağlayan simge ve ismidir (Çifci ve Cop 2007:70).

Tanımlardan da görüldügüü üzere marka çok boyutlu bir kavram olarak ele alınmaktadır. Markayı sadece isim veya şekil olarak tanımlamak oldukça yetersiz kalmaktadır. İsim, şekil, renk, sembol, ses, tasarım ve koku bile bir markaya özgü nitelikler taşıyabilmektedir (Türker ve Türker 2013:51). Marka, tüketici ihtiyaçları için seçebileceği ürünler arasından o işletmeyi tercihe yönlendiren, ürün-tüketici arasında gerçekleşen iletişimin 
psikolojik faktörlerinin bir bileşimi olarak ifade edilmektedir (Doğru ve Koçer 2016:133).

Marka değeri ile işletme performansı arasında pozitif ilişki olduğunu iddia eden çalışmalar vardır. Bu yüzden marka değeri önem arz etmektedir (Çetinsöz ve Artuğer 2013:201). Marka değeri, ürüne eklenen ilave değer veya tüketicilerin ürün hakkında algıladıkları değer olarak ifade edilebilir (Kim vd. 2008:77). Marka değeri algısının alt boyutları marka sadakati, marka farkındalı̆̆ı, marka çağrışımı ve algılanan kalitedir. Tüketici temelli marka değeri marka farkındalığı, marka imajı, algılanan kalite ve marka sadakati boyutlarından oluşmaktadır (Kim vd. 2003:336-337).

Günümüz literatüründe marka değeri finansal ve tüketici temelli olmak üzere iki şekilde incelenmektedir (Yazgan, Kethüda ve Çat1 2014:239). Bir de bu ikisinin birleşiminden oluşan pazarlama temelli marka değerini baz alan çalışmalar bulunmaktadır (Kim vd. 2003:336). Bu çalışma, tüketici temelli marka değerinde genellikle kabul edilen Aaker (1991)'in marka değeri algısı boyutları kullanılarak gerçekleştirilmiştir. Marka farkındalığ 1 ve marka çağrışımı boyutları kullanılan ölçekte aynı alt boyut altında değerlendirilmektedir.

\subsubsection{Marka Değeri Algısı Alt Boyutları}

Marka değerinin alt boyutları (sadakat, farkındalık, algılanan kalite, çağrışım, imaj) genel marka değeri üzerinde olumlu etkiye sahiptir. Böylelikle tüketicinin zihninde oluşan yüksek marka farkındalığı ile güçlü ve pozitif çağrışımlar marka tercihinin artmasına yol açar. Benzer şekilde algılanan yüksek kalite ve satın alma sıklığı tüketici temelli marka değerinin olumlu olmasını sağlamaktadır (Gil vd. 2007:191-192).

Sadakat, müşterinin belirli bir markaya olan ilgisini alternatif seçenekler bulunduğu zamanda da devam ettirmesidir. Müşteri sadakati ise bir firmanın finansal alt yapısında esaslı bir etkiye sahiptir (Cyr vd. 2007:43).

Marka sadakati ise pazarlama literatüründe en fazla dikkat çeken konulardan biridir. Bir markayı düzenli ve tutarlı bir şekilde satın alma isteği olarak tanımlanır (Türker ve Türker 2013:49). Pazarlamanın temelinde yer alan marka sadakati, bir müssterinin markaya olan bağlllı̆̆ının ölçüsüdür. Markaya bağlllık duymayan bir müşteri, fiyat veya ürün özelliklerinde bir değişiklik meydana geldiğinde bir başka markaya geçebilmektedir. Oysa marka sadakati arttıkça müşterinin rakip firmalara karşı olan zayıflığı azalmaktadır. Marka sadakatinin marka özvarlığının gelecek kârlarının bir göstergesi olduğu ifade edilebilir; 
çünkü sadakat gelecekteki satışların bir göstergesidir (Tosun ve Elmasoğlu 2015:94).

Kalitenin net bir tanımını yapmak zor olduğu gibi hizmet sektöründe kalitenin algılanması daha da zorluk arz etmektedir (Çetinsöz ve Artuğer 2013:203). Çünkü kalite algısının kavrandığı yer tüketici zihnidir. Kalite; ürün dayanıklılığı, güvenliği, sunuluşu gibi birçok nedene bağl1 alg1lanabilmektedir (Can 2007:229). Alg1lanan kalite, marka değerini ölçen temel boyutlardan biridir. Algılanan kalite, ürün ya da hizmetin alternatif markalarla kıyaslanarak ölçülmesiyle elde edilir (Aaker 1996:109). Tüketicinin marka hakkında fazla bilgiye sahip olmaması durumunda algılanan kalite satın alma niyetini etkileyebilmektedir. Algılanan kalite yüksek olduğu takdirde ürün hakkındaki belirsizlik azalacaktır. Belirsizlik fazla olursa tüketici kararını etkileyecektir. Diğer koşullar sabitken yüksek kaliteli marka tercih edilecektir. Tüketiciler açısından markanın algılanan kalitesinin yüksekliği marka için önemlidir (Pala 2017:99).

Marka farkındalığı; bir markanın tüketici tarafindan tanınması, hatırlanması, farkındalığı, bilgi sahibi olması ve markaya karşı tutumunu ifade etmektedir (Kim vd. 2008:77). Marka farkındalığı tüketicilerin farklı koşullar altında markayı zihinlerinde tanımlama becerileridir ve marka isminin tüketici zihnine kolay gelebilmesiyle ilgilidir. Markayı tanıma tüketicilere marka ile ilgili ipucu verildiğinde markayı doğrulama şeklinde gerçekleşir. Marka farkındalığı tüketici kararlarını verirken önemli rol oynayan üç sebepten biridir. Öncelikle alınmak istenen ürün kategorisinde o markanın zihne gelmesi gerekir. Marka farkındalığ1 artarsa markanın satışının da artması beklenir. İkincisi çok fazla ürün ve hizmet seti olmayan alanlarda dahi marka bilinirliği tüketiciler açısından önem arz etmektedir. Son olarak ise marka farkındalığı marka imajına etki etmekte ve bu durum ise satışlara olumlu yansımaktadır (Keller 1993:3).

\section{Yöntem}

\subsection{Araştırmanın Evren Ve Örneklemi}

Araştırmanın evrenini bankacılık ve finans bölümü bütün lisans öğrencileri oluşturmaktadır. Araştırmanın örneklemi ise Cumhuriyet Üniversitesi'nde öğrenim gören 199 ve Gazi Üniversitesi'nde öğrenim gören 154 bankacılık ve finans bölümü öğrencilerinden oluşmaktadır. Araştırmanın örneklemini oluşturan öğrencilere en kısa zamanda ve en az maliyetle ulaşılması amaçlandığından dolayı örneklemin belirlenmesinde kolayda örnekleme yöntemi tercih edilmiştir. 


\subsection{Veri Toplama Aracı}

Çalışmanın amacı doğrultusunda birincil verileri elde edebilmek için anket uygulamasına başvurulmuştur. Kullanılan anket formu 3 bölümden oluşmaktadır. Birinci bölümde araştırmaya katılan bireylerin demografik özelliklerini belirlemeye yönelik sorulara yer verilmiştir. İkinci bölümde bankalarda kurumsal sosyal sorumluluk algısını ölçen 5'li likert tipinde maddeler bulunmaktadır. Son bölümde ise marka değeri algısını ölçmeye yönelik 5'li likert tipinde maddelere yer verilmiştir. KSS algısı ölçeği için 5'li likert tipi ölçeği (1:Kesinlikle Katılmıyorum ve 5:Kesinlikle Katılıyorum) şeklinde uygulanmıştır. KSS algısının boyutlarını ölçmek üzere kullanılan ölçek Singh vd. (2008) ve Fahlioğulları (2009)'nın çalışmalarından yararlanılarak oluşturulmuştur. Marka değeri algısı ölçeği de yine 5'li likert tipinde bir ölçektir ve Yoo \& Donthu (2002) ile Engizek \& Yaşin (2016) çalışmalarından yararlanılarak oluşturulmuştur.

\subsection{Verilerin Toplanması}

Çalışmada veri toplama aracı olarak kullanılan ölçekler, Cumhuriyet Üniversitesi'nde ve Gazi Üniversitesi'nde Bankacillk ve Finans bölümünde öğrenim gören toplam 353 lisans öğrencisine yüz yüze olarak uygulanmış ve araştırmanın verileri elde edilmiştir.

\subsection{Araştırmanın Yöntemi}

Öncelikle ölçeklerin faktör yapısının belirlenmesinde açımlayıcı faktör analizi yöntemine başvurulmuştur. Elde edilen değişkenlerin normallik analizinde çarpıklık ve basıklık değerleri dikkate alınmıştır. Farklı grupların iki ölçeğe ve alt boyutlarına ait ortalama puanlarının karşılaştırılmasında ise grup sayısı dikkate alınmışıtır. Bu bağlamda bağımsız iki grubun ortalamalarının karşılaştırılmasında bağımsız gruplar için $\mathrm{t}$ testi, üç veya daha fazla sayıda grubun ortalamalarının karşılaştırılması için ise tek yönlü varyans analizi-Oneway Analysis of Variance (ANOVA) testi kullanılmıştır. ANOVA testinin sonucunda varsa farklılığın hangi gruplardan kaynaklandığını belirlemek için ise çoklu karşılaştırma testleri dikkate alınmıştır. Bu bağlamda grupların varyanslarının homojen olduğu durumda kullanılan çoklu karşılaştırma testlerinden Tukey çoklu karşılaştırma testi kullanılmıştır.

Tukey testi grup varyanslarının homojen olduğu durumda $\mathrm{k}$ adet ortalamayı ikili olarak ortak bir hata payıyla eş zamanlı karşılaştıran çoklu karşılaştırma testidir (Karagöz 2016:419). Söz konusu istatistiksel tekniklerin uygulanmasinda IBM SPSS 22 paket programından yararlanılmıştır. 


\section{Bulgular}

\section{1.Ölçek Yapısına ve Verilerin Güvenirliğine İlişkin Bulgular}

Araştırmada veri toplama aracı olarak kullanılan her iki ölçeğin faktör yapılarını ortaya koymak amacıyla verilere öncelikle açımlayıcı faktör analizi uygulanmıştır. KSS algısı ölçeği için KMO istatistiği 0,921 olarak hesaplanmış, Bartlett testi sonucunda ise $\chi^{2}=4032,890 ; p<0,001$ olarak bulunmuştur. $\mathrm{Bu}$ sonuçlara göre örneklem büyüklüğünün ve değişkenlerin faktör analizi için uygun olduğu tespit edilmiş ve yapılan açımlayıcı faktör analizi sonucunda üç faktörlü bir yapı elde edilmiştir. Döndürülmüş bileşenler matrisinden elde edilen faktör yük değerleri ve faktörlerin açıkladıkları varyans oranları Tablo 1'deki gibidir.

Tablo 1: KSS Ölçeği Alt Faktörleri ve Faktör Yük Değerleri

\begin{tabular}{|c|c|c|}
\hline Ticari Sorumluluk & $\begin{array}{l}\text { Faktör } \\
\text { Yükleri }\end{array}$ & $\begin{array}{l}\text { Açılklanan } \\
\text { Varyans }\end{array}$ \\
\hline $\begin{array}{l}\text { Bankam piyasaya devamlı olarak yeni hizmetler } \\
\text { sunmaktadır. }\end{array}$ & ,804 & \multirow{6}{*}{$\% 38,29$} \\
\hline Bankam yenilikçi bir bankadır. & ,745 & \\
\hline Bankamın sunduğu hizmetlerin kalitesi her zaman iyidir. & 693 & \\
\hline $\begin{array}{l}\text { Bankam ürün ve hizmetleri hakkında doğru ve gerçeğe } \\
\text { uygun bir biçimde bilgi verir. }\end{array}$ & ,602 & \\
\hline Bankam müşterilerin ihtiyaçlarını tatmin eder. &, 558 & \\
\hline $\begin{array}{l}\text { Bankam hizmet kalitesini yüksek tutmak için sürekli } \\
\text { çalışır. }\end{array}$ &, 520 & \\
\hline Etik Sorumluluk & $\begin{array}{l}\text { Faktör } \\
\text { Yükleri }\end{array}$ & $\begin{array}{l}\text { Açıklanan } \\
\text { Varyans }\end{array}$ \\
\hline $\begin{array}{l}\text { Bankam müşterilerine karş1 olan sorumluluklarını yerine } \\
\text { getirme konusunda duyarlıdır. }\end{array}$ & ,741 & \multirow{8}{*}{$\% 13,83$} \\
\hline $\begin{array}{l}\text { Bankam faaliyetlerini yürütürken tüketici haklarına } \\
\text { saygı gösterme konusunda duyarlıdır. }\end{array}$ &, 726 & \\
\hline $\begin{array}{l}\text { Bankam faaliyetlerini her zaman yasalarda belirtilen } \\
\text { kurallara uygun olarak yürütür. }\end{array}$ & ,692 & \\
\hline $\begin{array}{l}\text { Bankam için karşl1ıklı ilişkilerinde etik davranmak, daha } \\
\text { yüksek ekonomik performans elde etmekten önce gelir. }\end{array}$ &, 586 & \\
\hline Bankam müşterilerine dürüst davranır. &, 503 & \\
\hline Bankam müşterilerinin haklarını gönüllü olarak korur. & ,493 & \\
\hline Bankam müşterilerini asla aldatmaz. & ,452 & \\
\hline Hizmet aldığım bankanın etik itibarı önemlidir. & 437 & \\
\hline Sosyal Sorumluluk & $\begin{array}{l}\text { Faktör } \\
\text { Yükleri }\end{array}$ & $\begin{array}{c}\text { Açıklanan } \\
\text { Varyans }\end{array}$ \\
\hline Bankam doğal çevreyi koruma konusunda duyarlıdır. & ,762 & \multirow[b]{2}{*}{$\% 8,11$} \\
\hline $\begin{array}{l}\text { Bankam bütçesinin bir kısmını sosyal projelere ayırarak } \\
\text { toplumun nispeten daha zayıf gruplarına yardımc1 }\end{array}$ &, 740 & \\
\hline
\end{tabular}




\begin{tabular}{|l|c|}
\hline olmayı amaçlar. & \\
\hline $\begin{array}{l}\text { Bankam sosyal ve/veya kültürel faaliyetleri } \\
\text { destekleyerek toplumun gelişmesine destek olur. }\end{array}$ &, 734 \\
\hline $\begin{array}{l}\text { Bankam toplumun refahını artırma konusunda } \\
\text { duyarlıdır. }\end{array}$ &, 710 \\
\hline Bankam toplumun sorunlarına karşı duyarlıdır. &, 696 \\
\hline $\begin{array}{l}\text { Bankam toplumun sorunları söz konusu olduğunda } \\
\text { sorumluluk duygusuyla hareket eder. }\end{array}$ &, 642 \\
\hline $\begin{array}{l}\text { Etik ve sosyal açıdan sorumlu davranmayan bankalardan } \\
\text { hizmet almaktan kaçınırım. }\end{array}$ &, 583 \\
\hline $\begin{array}{l}\text { İki banka maliyet ve hizmet kalitesi açısından aynı ise } \\
\text { etik ve sosyal açıdan sorumluluğa sahip bankayı tercih } \\
\text { ederim. }\end{array}$ &, 542 \\
\hline $\begin{array}{l}\text { Sosyal sorumluluk projelerine daha fazla önem veren } \\
\text { bankadan hizmet almak için daha fazla para ödemeye } \\
\text { razı olurum. }\end{array}$ &, 461 \\
\hline $\begin{array}{l}\text { Hizmet aldı̆ı̆m bankanın sosyal sorumluluk } \\
\text { faaliyetlerini göz önünde bulundururum. }\end{array}$ &, 437 \\
\hline
\end{tabular}

Tablo 1'deki bulgulara göre ticari sorumluluk faktörü toplam varyansın \%38,29'unu, etik sorumluluk faktörü toplam varyansın \%13,83'ünü, sosyal sorumluluk faktörü ise toplam varyansın \%8,11'ini açıklamaktadır. $\mathrm{Bu}$ üç faktör birlikte KSS algısının \%60,23’ünü açıklamaktadırlar.

Marka değeri alg1sı ölçeği için ise KMO istatistiği 0,919 olarak hesaplanırken, Bartlett testi sonucunda ise $\chi^{2}=3252,895 ; \mathrm{p}<0,001$ olarak bulunmuştur. $\mathrm{Bu}$ bulgulara göre örneklem büyüklüğünün ve değişkenlerin faktör analizi için uygun olduğu belirlenerek yapılan açımlayıcı faktör analizi sonucunda dört faktörlü bir yapı elde edilmiştir. Döndürülmüş bileşenler matrisi sonucunda edilen faktör yük değerleri ve faktörlerin açıkladıkları varyans oranları Tablo 2'deki gibidir.

Tablo 2: Marka Değeri Algısı Ölçeği Alt Faktörleri ve Faktör Yük Değerleri

\begin{tabular}{|c|c|c|}
\hline Marka Sadakati & $\begin{array}{l}\text { Faktör } \\
\text { Yükleri }\end{array}$ & $\begin{array}{l}\text { Açıklanan } \\
\text { Varyans }\end{array}$ \\
\hline $\begin{array}{l}\text { Kendimi hizmet aldığım bankanın sadık bir müşterisi } \\
\text { olarak görüyorum. }\end{array}$ & ,727 & \multirow{4}{*}{$\% 13,44$} \\
\hline $\begin{array}{l}\text { Hizmet aldığım banka gelecekte de ilk tercihim olmaya } \\
\text { devam edecektir. }\end{array}$ & ,726 & \\
\hline $\begin{array}{l}\text { Hizmet aldığım banka varken diğer bankaların } \\
\text { hizmetlerini almayı düşünmem. }\end{array}$ & 691 & \\
\hline Hizmet aldığım bankayı başkalarına da tavsiye ederim. & 658, & \\
\hline Algılanan Kalite & $\begin{array}{l}\text { Faktör } \\
\text { Yükleri }\end{array}$ & $\begin{array}{l}\text { Açılanan } \\
\text { Varyans }\end{array}$ \\
\hline Bankamın hizmetleri güvenilirdir. &, 805 & $\% 31,43$ \\
\hline
\end{tabular}




\begin{tabular}{|c|c|c|}
\hline Bankamın hizmetlerinin kalitesi istikrarlıdır. & ,775 & \\
\hline $\begin{array}{l}\text { Hizmet aldığım bankanın her ihtiyaca hitap eden } \\
\text { fonksiyonel/pratik ürün ve hizmetleri vardır. }\end{array}$ & ,700 & \\
\hline $\begin{array}{l}\text { Hizmet aldığım bankanın oldukça yüksek kalitede ürün ve } \\
\text { hizmet sunduğuna inancım tamır. }\end{array}$ & 699 & \\
\hline Bankamın hizmetleri kalitelidir. & ,662 & \\
\hline Bankamın hizmetlerinin kalitesi istikrarlıdır. & ,614 & \\
\hline Marka Farkındalığı & $\begin{array}{l}\text { Faktör } \\
\text { Yükleri }\end{array}$ & $\begin{array}{l}\text { Açıklanan } \\
\text { Varyans }\end{array}$ \\
\hline Bankamın hizmetlerinin neler olduğunu biliyorum. &, 777 & \multirow{5}{*}{$\% 9,57$} \\
\hline $\begin{array}{l}\text { Hizmet aldığım bankayı rakipleri arasından kolaylıkla } \\
\text { ayırt edebilirim. }\end{array}$ & 693 & \\
\hline $\begin{array}{l}\text { Hizmet aldığım bankanın özellikleri aklıma hemen } \\
\text { geliverir. }\end{array}$ &, 582 & \\
\hline $\begin{array}{l}\text { Hizmet aldığım bankanın logosunu veya sembolünü } \\
\text { hemen hatırlarım. }\end{array}$ &, 558 & \\
\hline $\begin{array}{l}\text { Hizmet aldığım bankayı gözümde canlandırmakta } \\
\text { zorlanırım. }\end{array}$ &, 777 & \\
\hline Genel Marka Değeri & $\begin{array}{l}\text { Faktör } \\
\text { Yükleri }\end{array}$ & $\begin{array}{l}\text { Açıklanan } \\
\text { Varyans }\end{array}$ \\
\hline $\begin{array}{l}\text { Diğer bankalar ile hizmet aldığım banka, hizmet ve } \\
\text { projeleri bakımından birebir aynı olsa dahi o banka yerine } \\
\text { hizmet aldığım bankayı tercih ederim. }\end{array}$ & ,613 & \multirow{4}{*}{$\% 7,74$} \\
\hline $\begin{array}{l}\text { Diğer bankalar hizmet aldığım banka ile aynı özelliklere } \\
\text { sahip olsalar bile ben yine hizmet aldığım bankayı tercih } \\
\text { ederim. }\end{array}$ &, 556 & \\
\hline $\begin{array}{l}\text { Hizmet aldığım banka kadar iyi bir başka banka olsa dahi } \\
\text { ben yine hizmet aldığım bankayı tercih ederim. }\end{array}$ &, 549 & \\
\hline $\begin{array}{l}\text { Diğer bankaların hizmet aldığım bankadan hiçbir fark1 } \\
\text { olmasa bile bankamdan hizmet almak daha akıllıcadır. }\end{array}$ &, 517 & \\
\hline
\end{tabular}

Tablo 2'deki bulgulara göre marka sadakati faktörü toplam varyansın \%13,44'ünü, algilanan kalite faktörü toplam varyansın \%31,43'ünü, marka farkındalığı faktörü toplam varyansın \%9,57'sini, genel marka değeri faktörü ise toplam varyansın \%7,74’ünü açıklamaktadır. Bu dört faktörlü yap1 birlikte marka değeri algısının \%62,18'ini açıklamaktadirlar.

Her iki ölçeğin tamamının ve alt boyutlarının yapılan uygulama sonucunda hesaplanan Cronbach Alpha katsayıları ise Tablo 3'teki gibidir:

Tablo 3: Ölçekler ve Alt Faktörlerinin Cronbach $\alpha$ Katsayıları

\begin{tabular}{|l|lc|c|c|}
\hline \multicolumn{2}{|c|}{ Ölçekler ve Alt Boyutları } & $\begin{array}{c}\text { Değişken } \\
\text { Sayısı }\end{array}$ & $\begin{array}{c}\text { Cronbach Alpha İç } \\
\text { Tutarlılık Katsayısı (a) }\end{array}$ \\
\hline Ölçek & Kurumsal & Sosyal & 24 & 0,927 \\
\hline
\end{tabular}




\begin{tabular}{|c|c|c|c|}
\hline & Sorumluluk & & \\
\hline \multirow{3}{*}{$\begin{array}{l}\text { Alt } \\
\text { Boyutlar }\end{array}$} & $\begin{array}{l}\text { Faktör 1: } \quad \text { Ticari } \\
\text { Sorumluluk }\end{array}$ & 6 & 0,844 \\
\hline & $\begin{array}{l}\text { Faktör 2: } \\
\text { Sorumluluk }\end{array}$ & 8 & 0,855 \\
\hline & $\begin{array}{ll}\text { Faktör 3: } & \text { Sosyal } \\
\text { Sorumluluk } & \end{array}$ & 10 & 0,834 \\
\hline Ölçek & Marka Değeri Algısı & 19 & 0,911 \\
\hline \multirow{4}{*}{$\begin{array}{l}\text { Alt } \\
\text { Boyutlar }\end{array}$} & $\begin{array}{lll}\text { Faktör 1: } & \text { Marka } \\
\text { Sadakati } & & \end{array}$ & 4 & 0,763 \\
\hline & $\begin{array}{l}\text { Faktör 2: Algilanan } \\
\text { Kalite }\end{array}$ & 6 & 0,888 \\
\hline & $\begin{array}{lrl}\text { Faktör 3: } & \text { Marka } \\
\text { Farkındalığı } & \\
\end{array}$ & 5 & 0,789 \\
\hline & $\begin{array}{l}\text { Faktör 4: } \quad \text { Genel } \\
\text { Marka Değeri }\end{array}$ & 4 & 0,849 \\
\hline
\end{tabular}

Tablo 3 'teki bulgulara göre her iki ölçeğin ve alt boyutlarının tamamının Cronbach $\alpha$ katsayılarının 0,70 'ten büyük olduğu ve dolayısıyla yüksek güvenirliğe sahip olduğu söylenebilir. $\mathrm{Bu}$ bilgiler doğrultusunda KSS ölçeğinin ve Marka Değeri Algısı ölçeğinin çalışma kapsamında kullanılabilecek güvenilir birer ölçme aracı oldukları belirlenmiştir.

\subsection{Demografik Bulgular}

Araştırmada demografik değişken olarak yer verilen cinsiyet, üniversite ve ailesinin aylı geliri değişkenleriyle birlikte öğrencilerin KSS hakkında bilgisi olup olmadığı, bankasının KSS projeleri hakkında bilgi sahibi olup olmadığı ve bankasının en çok hangi hizmetini kullandığ hakkında bilgi edinmek için kategorik sorulara yer verilmiştir. $\mathrm{Bu}$ değişkenlere ait frekans ve yüzde değerleri Tablo 4'teki gibi elde edilmiştir:

Tablo 4: Demografik Değişkenlere Ait Frekans Tablosu

\begin{tabular}{|l|c|c|}
\hline Cinsiyet & Frekans & Yüzde \\
\hline K1z & 226 & 64,0 \\
\hline Erkek & 127 & 36,0 \\
\hline Üniversite & Frekans & Yüzde \\
\hline Cumhuriyet & 199 & 56,4 \\
\hline Gazi & 154 & 43,6 \\
\hline Ailesinin Aylık Geliri & Frekans & Yüzde \\
\hline 1500 TL ve alt1 & 99 & 28,0 \\
\hline 1501-3000 TL aras1 & 146 & 41,4 \\
\hline 3001-4500 TL aras1 & 65 & 18,4 \\
\hline 4501-6000 TL aras1 & 30 & 8,5 \\
\hline 6001 TL ve üzeri & 13 & 3,7 \\
\hline
\end{tabular}




\begin{tabular}{|l|c|c|}
\hline KSS hakkında bilginiz var mı? & Frekans & Yüzde \\
\hline Evet & 81 & 22,9 \\
\hline Hayır & 272 & 77,1 \\
\hline Bankanızın KSS projelerinden haberdar mısınız? & Frekans & Yüzde \\
\hline Evet & 39 & 11,0 \\
\hline Hayır & 314 & 89,0 \\
\hline Bankanızın en çok hangi hizmetinden yararlanıyorsunuz? & Frekans & Yüzde \\
\hline Vadesiz Mevduat Hesab1 & 147 & 41,6 \\
\hline Vadeli Mevduat Hesabı & 11 & 3,1 \\
\hline Kredi Kart & 91 & 25,8 \\
\hline Kredi & 13 & 3,7 \\
\hline Otomatik Ödemeler & 12 & 3,4 \\
\hline İnternet-Telefon Bankacılığ1 & 48 & 13,6 \\
\hline Diğer & 31 & 8,8 \\
\hline
\end{tabular}

Tablo 4’teki bulgulara göre öğrencilerin yaklaşı \%23'ü kurumsal sosyal sorumluluk hakkında bilgi sahibiyken \%77'si bilgi sahibi değildir. Yine öğrencilerin sadece \%11'i bankasının kurumsal sosyal sorumluluk projelerinden haberdar iken \%89'u bu konuda herhangi bir bilgiye sahip değildir. Öğrencilerin bankasının en çok hangi hizmetinden yararlandığına bakılacak olursa yaklaşık \%42'sinin vadesiz mevduat hesabını, \%26'sının kredi kartı hizmetini, \%14'ünün ise internet-telefon bankacılığg hizmetini en çok kullandıkları görülmektedir.

\subsection{KSS Algısı ve Marka Değeri Algısının Demografik Değişkenlere Göre İncelenmesi}

KSS ölçeği ve alt boyutlarıyla birlikte Marka Değeri Algısı ölçeği ve alt boyutlarına ait hesaplanan ortalama puanlarına ilişkin bazı betimleyici istatistikler Tablo 5'te verilmiştir.

Tablo 5: Ölçek ve Faktör Puanlarına Ait Betimleyici İstatistikler

\begin{tabular}{|c|c|c|c|c|c|c|}
\hline \multicolumn{2}{|c|}{ Ölçekler ve Alt Boyutları } & \multirow{2}{*}{$\frac{\mathrm{N}}{353}$} & \multirow{2}{*}{$\begin{array}{l}\text { Ort. } \\
3,38\end{array}$} & \multirow{2}{*}{$\begin{array}{c}\text { ss. } \\
0,62\end{array}$} & \multirow{2}{*}{$\begin{array}{c}\text { Çarpıklık } \\
-0,307\end{array}$} & \multirow{2}{*}{$\begin{array}{r}\text { Basıklık } \\
1,079\end{array}$} \\
\hline Ölçek & $\begin{array}{ll}\text { Kurumsal } & \text { Sosyal } \\
\text { Sorumluluk } & \end{array}$ & & & & & \\
\hline \multirow{3}{*}{$\begin{array}{l}\text { Alt } \\
\text { Boyutlar }\end{array}$} & Ticari Sorumluluk & 353 & 3,38 & 0,72 & $-0,624$ & 0,804 \\
\hline & Etik Sorumluluk & 353 & 3,39 & 0,71 & $-0,418$ & 0,610 \\
\hline & Sosyal Sorumluluk & 353 & 3,36 & 0,66 & $-0,280$ & 0,593 \\
\hline Ölçek & Marka Değeri Algısı & 353 & 3,29 & 0,70 & $-0,483$ & 0,401 \\
\hline \multirow{2}{*}{$\begin{array}{l}\text { Alt } \\
\text { Boyutlar }\end{array}$} & Marka Sadakati & 353 & 3,24 & 0,95 & $-0,337$ & $-0,261$ \\
\hline & Algılanan Kalite & 353 & 3,42 & 0,83 & $-0,451$ & 0,367 \\
\hline
\end{tabular}




\begin{tabular}{|l|l|c|c|c|c|c|}
\hline & Marka Farkındalı̆̆ı & 353 & 3,17 & 0,73 & $-0,523$ & 0,588 \\
\cline { 2 - 7 } & Genel Marka Değeri & 353 & 3,32 & 0,95 & $-0,252$ & $-0,106$ \\
\hline
\end{tabular}

Her iki ölçek ve alt boyutlarının ortalama puanlarının normal dağılım gösterip göstermediğini belirlemek amacıyla çarpıklık ve basıklık değerleri dikkate alınmıştır. Çünkü özellikle likert ölçek üzerinden elde edilen değişkenlerin normallik sınaması için literatürde kabul gören bir kriter çarpıklık katsayısının \pm 1 aralığında, basıklık katsayısının ise \pm 2 aralığında değer almasıdır (Tabachnick ve Fidell 2007; Akt: Ilgaz 2015:878). Bu doğrultuda, Tablo 3'teki her iki ölçek ve alt boyutlarının çarpıklık ve basıklık değerleri göz önüne alındığında normal dağılıma yakın bir dağılım gösterdikleri kabul edilebilir. Buna göre kurumsal sosyal sorumluluk ve alt boyutlarının ve marka algısı ve alt boyutlarının ortalama puanlarının çeşitli demografik değişkenlere göre anlamlı bir farkl1lık gösterip göstermediğinin incelenmesinde parametrik istatistiksel yöntemler kullanılmıştır.

Öncelikle öğrencilerin algıladıkları bankalarının kurumsal sosyal sorumluluk ve alt boyut puanlarının cinsiyete göre anlamlı bir farklılık gösterip göstermediği bağımsız gruplar için $\mathrm{t}$ testi ile incelenmiştir. Burada dikkate alınan Levene varyansların homojenliği testi sonucuna göre cinsiyet gruplarının varyanslarının homojen olup olmadığı tespit edilmiş, bu doğrultuda hesaplanan $t$ test istatistiği dikkate alınmıştır. Elde edilen bulgular Tablo 6'daki gibidir.

Tablo 6: Cinsiyete Göre Faktör Puanlarına İlişkin t Testi Sonuçları

\begin{tabular}{|c|c|c|c|c|c|c|c|}
\hline & Cinsiyet & $\mathbf{N}$ & Ort & SS & $\begin{array}{l}\text { Varyansların } \\
\text { Homojenliği }\end{array}$ & $\mathbf{t}$ & $\mathbf{p}$ \\
\hline \multirow{2}{*}{$\begin{array}{l}\text { Kurumsal Sosyal } \\
\text { Sorumluluk }\end{array}$} & Kiz & 226 & 3,41 &, 58 & \multirow{2}{*}{ Homojen } & \multirow{2}{*}{1,325} & \multirow{2}{*}{0,186} \\
\hline & Erkek & 127 & 3,32 & ,69 & & & \\
\hline \multirow{2}{*}{ Ticari Sorumluluk } & $\mathrm{K} 1 \mathrm{Z}$ & 226 & 3,38 & ,69 & \multirow{2}{*}{ Homojen } & \multirow{2}{*}{0,001} & \multirow{2}{*}{0,999} \\
\hline & Erkek & 127 & 3,38 & ,79 & & & \\
\hline \multirow{2}{*}{ Etik Sorumluluk } & $\mathrm{K} 1 \mathrm{z}$ & 226 & 3,43 & ,67 & \multirow{2}{*}{ Homojen } & \multirow{2}{*}{1,479} & \multirow{2}{*}{0,140} \\
\hline & Erkek & 127 & 3,31 & ,79 & & & \\
\hline \multirow{2}{*}{$\begin{array}{l}\text { Sosyal } \\
\text { Sorumluluk }\end{array}$} & $\mathrm{K} 1 \mathrm{z}$ & 226 & 3,39 & ,60 & \multirow{2}{*}{ Homojen } & \multirow{2}{*}{1,514} & \multirow{2}{*}{0,131} \\
\hline & Erkek & 127 & 3,29 & ,74 & & & \\
\hline
\end{tabular}

Tablo 6'daki bulgulara göre öğrencilerin algıladıkları kurumsal sosyal sorumluluk puanları ve alt boyutlarının hiçbiri için cinsiyete göre anlamlı bir farklılık tespit edilmemiştir ( $\mathrm{p}>0,05)$.

İkinci olarak öğrencilerin algıladıkları bankalarının kurumsal sosyal sorumluluk ve alt boyut puanlarının öğrenim gördükleri üniversiteye göre anlamlı bir farklılık gösterip göstermediği yine bağımsız gruplar için $\mathrm{t}$ testi ile incelenmiştir. Elde edilen bulgular Tablo 7'deki gibidir. 
Tablo 7: Üniversiteye Göre Faktör Puanlarına İlişkin ANOVA Testi Sonuçları

\begin{tabular}{|c|c|c|c|c|c|c|c|}
\hline & Üniversite & $\mathbf{N}$ & Ort & ss & $\begin{array}{l}\text { Varyansların } \\
\text { Homojenliği }\end{array}$ & $\mathbf{t}$ & $\mathbf{p}$ \\
\hline \multirow{2}{*}{$\begin{array}{l}\text { Kurumsal } \\
\text { Sosyal } \\
\text { Sorumluluk }\end{array}$} & Cumhuriyet & 199 & 3,36 & ,62 & \multirow[b]{2}{*}{ Homojen } & \multirow[b]{2}{*}{$-0,363$} & \multirow[b]{2}{*}{0,717} \\
\hline & Gazi & 154 & 3,38 & ,61 & & & \\
\hline \multirow{2}{*}{$\begin{array}{l}\text { Ticari } \\
\text { Sorumluluk }\end{array}$} & Cumhuriyet & 199 & 3,35 &, 70 & \multirow{2}{*}{ Homojen } & \multirow{2}{*}{$-0,598$} & \multirow{2}{*}{0,550} \\
\hline & Gazi & 154 & 3,40 &, 75 & & & \\
\hline \multirow{2}{*}{$\begin{array}{l}\text { Etik } \\
\text { Sorumluluk }\end{array}$} & Cumhuriyet & 199 & 3,37 & ,72 & \multirow{2}{*}{ Homojen } & \multirow{2}{*}{$-0,312$} & \multirow{2}{*}{0,755} \\
\hline & Gazi & 154 & 3,40 & ,70 & & & \\
\hline \multirow{2}{*}{$\begin{array}{l}\text { Sosyal } \\
\text { Sorumluluk }\end{array}$} & Cumhuriyet & 199 & 3,34 & ,67 & \multirow{2}{*}{ Homojen } & \multirow{2}{*}{$-0,411$} & \multirow{2}{*}{0,682} \\
\hline & Gazi & 154 & 3,37 & ,64 & & & \\
\hline
\end{tabular}

Tablo 7'deki bulgulara göre öğrencilerin algıladıkları kurumsal sosyal sorumluluk puanları ve alt boyutlarının hiçbiri için öğrenim gördükleri üniversiteye göre de anlamlı bir farkl1lık bulunmamıştır ( $>0,05)$.

Yine öğrencilerin algıladıkları bankalarının kurumsal sosyal sorumluluk ve alt boyut puanlarının kurumsal sosyal sorumluluk (KSS) hakkında bilgi sahibi olup olmadıklarına göre anlamlı bir farklılık gösterip göstermediği bağımsız gruplar için $\mathrm{t}$ testi ile incelenmiştir ve Tablo 8 'deki sonuçlar elde edilmiştir.

Tablo 8: KSS Hakkında Bilgi Sahibi Olmaya Göre Faktör Puanlarına İlişkin ANOVA Testi Sonuçları

\begin{tabular}{|c|c|c|c|c|c|c|c|}
\hline & $\begin{array}{l}\text { KSS } \\
\text { hakkında } \\
\text { bilgisi var } \\
\text { mı }\end{array}$ & $\mathbf{N}$ & Ort & SS & $\begin{array}{l}\text { Varyansların } \\
\text { Homojenliği }\end{array}$ & $\mathbf{t}$ & p \\
\hline \multirow{2}{*}{$\begin{array}{l}\text { Kurumsal } \\
\text { Sosyal } \\
\text { Sorumluluk }\end{array}$} & Evet & 81 & 3,45 & ,63 & \multirow{2}{*}{ Homojen } & \multirow{2}{*}{1,217} & \multirow{2}{*}{0,224} \\
\hline & Hayır & 272 & 3,35 & 62 & & & \\
\hline \multirow{2}{*}{$\begin{array}{l}\text { Ticari } \\
\text { Sorumluluk }\end{array}$} & Evet & 81 & 3,52 & ,72 & \multirow{2}{*}{ Homojen } & \multirow{2}{*}{2,100} & \multirow{2}{*}{0,036} \\
\hline & Hayır & 272 & 3,33 &, 71 & & & \\
\hline \multirow{2}{*}{$\begin{array}{l}\text { Etik } \\
\text { Sorumluluk }\end{array}$} & Evet & 81 & 3,42 &, 76 & \multirow{2}{*}{ Homojen } & \multirow{2}{*}{0,571} & \multirow{2}{*}{0,568} \\
\hline & Hayır & 272 & 3,37 & ,70 & & & \\
\hline \multirow{2}{*}{$\begin{array}{l}\text { Sosyal } \\
\text { Sorumluluk }\end{array}$} & Evet & 81 & 3,42 &, 65 & \multirow{2}{*}{ Homojen } & \multirow{2}{*}{1,046} & \multirow{2}{*}{0,296} \\
\hline & Hayır & 272 & 3,33 &, 65 & & & \\
\hline
\end{tabular}

Tablo 8'deki bulgulara göre öğrencilerin algıladıkları kurumsal sosyal sorumluluk puanları, etik sorumluluk puanları ve sosyal sorumluluk puanları KSS hakkında bilgi sahibi olup olmadıklarına göre anlamlı bir farklılık göstermezken $(\mathrm{p}>0,05)$, ticari sorumluluk puanları anlamlı bir farklılık göstermektedir $(\mathrm{p}<0,05)$. Bununla birlikte grup ortalamaları da 
dikkate alındığında KSS hakkında bilgi sahibi olan öğrencilerin bankalarının ticari sorumluluğuna yönelik algılarının daha yüksek olduğu söylenebilir.

Bankalarda uygulanan KSS faaliyetlerinden öğrencilerin algıladıkları KSS ve alt boyut puanlarının ailelerinin aylık gelirlerine göre anlamlı bir farkl1lık gösterip göstermediği durumu ise tek yönlü varyans analizi (ANOVA) ile incelenmiştir. Elde edilen bulgular Tablo 9'daki gibidir.

Tablo 9: Ailenin Gelirine Göre Faktör Puanlarına İlişkin ANOVA Testi Sonuçları

\begin{tabular}{|c|c|c|c|c|c|c|}
\hline & $\begin{array}{l}\text { Varyans } \\
\text { Kaynağı }\end{array}$ & $\begin{array}{l}\text { Kareler } \\
\text { Toplamı }\end{array}$ & $\begin{array}{c}\text { Serbestlik } \\
\text { Derecesi }\end{array}$ & $\begin{array}{c}\text { Kareler } \\
\text { Ort. }\end{array}$ & $\mathbf{F}$ & $\mathbf{p}$ \\
\hline \multirow{3}{*}{$\begin{array}{l}\text { Kurumsal } \\
\text { Sosyal } \\
\text { Sorumluluk }\end{array}$} & $\begin{array}{l}\text { Gruplar } \\
\text { Aras1 }\end{array}$ & 1,034 & 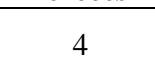 & ,258 & \multirow{3}{*}{0,662} & \multirow{3}{*}{ 619 } \\
\hline & Gruplar İçi & 135,7 & 348 & 390 & & \\
\hline & Toplam & 136,7 & 352 & & & \\
\hline \multirow{3}{*}{$\begin{array}{l}\text { Ticari } \\
\text { Sorumluluk }\end{array}$} & $\begin{array}{l}\text { Gruplar } \\
\text { Aras1 }\end{array}$ & 3,255 & 4 & ,814 & \multirow{3}{*}{1,569} & \multirow{3}{*}{, 182} \\
\hline & Gruplar İçi & 180,5 & 348 & ,519 & & \\
\hline & Toplam & 183,7 & 352 & & & \\
\hline \multirow{3}{*}{$\begin{array}{l}\text { Etik } \\
\text { Sorumluluk }\end{array}$} & $\begin{array}{l}\text { Gruplar } \\
\text { Aras1 }\end{array}$ & 1,176 & 4 & ,294 & \multirow{3}{*}{0,570} & \multirow{3}{*}{,684 } \\
\hline & Gruplar İçi & 179,3 & 348 &, 515 & & \\
\hline & Toplam & 180,5 & 352 & & & \\
\hline \multirow{3}{*}{$\begin{array}{l}\text { Sosyal } \\
\text { Sorumluluk }\end{array}$} & $\begin{array}{l}\text { Gruplar } \\
\text { Aras1 }\end{array}$ & ,444 & 4 &, 111 & \multirow{3}{*}{0,254} & \multirow{3}{*}{,907 } \\
\hline & Gruplar İçi & 151,7 & 348 & ,436 & & \\
\hline & Toplam & 152,1 & 352 & & & \\
\hline
\end{tabular}

Tablo 9'daki bulgulara göre öğrencilerin algıladıkları kurumsal sosyal sorumluluk puanlarının, etik sorumluluk puanlarının, sosyal sorumluluk puanlarının ve ticari sorumluluk puanlarının hiçbirisi öğrencinin ailesinin gelirine göre anlamlı bir farkl1lık göstermemektedir ( $p>0,05)$.

Öğrencilerin bankalarına yönelik marka değeri algıları ve alt boyut puanlarının cinsiyete göre anlamlı bir farklılık gösterip göstermediği yine bağımsız gruplar için t testi ile incelenmiştir. Elde edilen bulgular Tablo 10'daki gibidir.

Tablo 10: Cinsiyete Göre Faktör Puanlarına İlişkin t Testi Sonuçları

\begin{tabular}{|c|c|c|c|c|c|c|c|}
\hline & Cinsiyet & $\mathbf{N}$ & Ort & SS & $\begin{array}{l}\text { Varyansların } \\
\text { Homojenliği }\end{array}$ & $\mathbf{t}$ & $\mathbf{p}$ \\
\hline \multirow{2}{*}{$\begin{array}{l}\text { Marka } \\
\text { Değeri } \\
\text { Algis1 }\end{array}$} & Kiz & 226 & 3,34 & ,66 & \multirow[b]{2}{*}{ Homojen } & \multirow[b]{2}{*}{1,866} & \multirow[b]{2}{*}{0,063} \\
\hline & Erkek & 127 & 3,20 & ,76 & & & \\
\hline \multirow{2}{*}{$\begin{array}{l}\text { Marka } \\
\text { Sadakati }\end{array}$} & $\mathrm{K} 1 \mathrm{z}$ & 226 & 3,33 & ,91 & \multirow{2}{*}{ Homojen } & \multirow{2}{*}{2,646} & \multirow{2}{*}{0,009} \\
\hline & Erkek & 127 & 3,06 & ,98 & & & \\
\hline
\end{tabular}




\begin{tabular}{|l|l|l|l|l|l|l|l|}
\hline $\begin{array}{l}\text { Algılanan } \\
\text { Kalite }\end{array}$ & Kız & 226 & 3,50 &, 76 & \multirow{2}{*}{ Homojen Değil } & 2,430 & 0,016 \\
\cline { 2 - 5 } $\begin{array}{l}\text { Marka } \\
\text { Farkındalığı } 1\end{array}$ & Krkek & 127 & 3,26 &, 91 & & \\
\cline { 2 - 5 } & Erkek & 122 & 3,14 &, 71 & Homojen & 0,823 & 0,411 \\
\hline $\begin{array}{l}\text { Genel } \\
\text { Marka } \\
\text { Değeri }\end{array}$ & Kız & 226 & 3,36 &, 94 & Homojen & 1,441 & 0,151 \\
\cline { 2 - 5 } & Erkek & 127 & 3,21 &, 94 & & & \\
\hline
\end{tabular}

Tablo 10'daki bulgulara göre öğrencilerin genel marka alg1s1, marka farkındalığı ve marka değeri puanları cinsiyete göre anlamlı bir farklılık göstermezken ( $\mathrm{p}>0,05)$, marka sadakatleri ve alg1lanan kalite puanları ise anlamlı bir farklılı göstermektedir $(\mathrm{p}<0,05)$. Bununla birlikte grup ortalamaları da göz önünde bulundurulursa kız öğrencilerin marka sadakatlerinin ve algılanan kalite puanlarının erkeklere göre daha yüksek olduğu görülmektedir.

Öğrencilerin bankalarına yönelik marka algıları ve alt boyut puanlarının öğrenim gördükleri üniversiteye göre anlamlı bir farklılık gösterip göstermediği yine bağımsız gruplar için t testi ile incelenmiştir. Elde edilen bulgular Tablo 11'de verilmiştir.

Tablo 11: Üniversiteye Göre Faktör Puanlarına İlişkin ANOVA Testi Sonuçları

\begin{tabular}{|c|c|c|c|c|c|c|c|}
\hline & Üniversite & $\mathbf{N}$ & Ort & SS & $\begin{array}{l}\text { Varyansların } \\
\text { Homojenliği }\end{array}$ & $\mathbf{t}$ & $\mathbf{p}$ \\
\hline \multirow{2}{*}{$\begin{array}{l}\text { Marka } \\
\text { Algis1 }\end{array}$} & Cumhuriyet & 199 & 3,30 & ,76 & \multirow{2}{*}{ Homojen } & \multirow{2}{*}{0,339} & \multirow{2}{*}{0,734} \\
\hline & Gazi & 154 & 3,27 & ,62 & & & \\
\hline \multirow{2}{*}{$\begin{array}{l}\text { Marka } \\
\text { Sadakati }\end{array}$} & Cumhuriyet & 199 & 3,30 & 1,01 & \multirow{2}{*}{ Homojen } & \multirow{2}{*}{1,489} & \multirow{2}{*}{0,137} \\
\hline & Gazi & 154 & 3,15 &, 84 & & & \\
\hline \multirow{2}{*}{$\begin{array}{l}\text { Algilanan } \\
\text { Kalite }\end{array}$} & Cumhuriyet & 199 & 3,43 & ,86 & \multirow{2}{*}{ Homojen } & \multirow{2}{*}{0,471} & \multirow{2}{*}{0,638} \\
\hline & Gazi & 154 & 3,39 &, 78 & & & \\
\hline \multirow{2}{*}{$\begin{array}{l}\text { Marka } \\
\text { Farkındalığı }\end{array}$} & Cumhuriyet & 199 & 3,13 &, 79 & \multirow{2}{*}{ Homojen Değil } & \multirow{2}{*}{$-1,177$} & \multirow{2}{*}{0,240} \\
\hline & Gazi & 154 & 3,22 & ,61 & & & \\
\hline \multirow{2}{*}{$\begin{array}{l}\text { Marka } \\
\text { Değeri }\end{array}$} & Cumhuriyet & 199 & 3,32 & 1,02 & \multirow{2}{*}{ Homojen Değil } & \multirow{2}{*}{0,149} & \multirow{2}{*}{0,881} \\
\hline & Gazi & 154 & 3,30 &, 83 & & & \\
\hline
\end{tabular}

Tablo 11'deki bulgulara göre öğrencilerin bankalarına yönelik marka algılarının ve alt boyut puanlarının tamamının öğrenim gördükleri üniversiteye göre anlamlı bir farklılık göstermediği söylenebilir ( $\mathrm{p}>0,05)$.

Son olarak öğrencilerin bankalarına yönelik marka algıları ve alt boyut puanlarının ailelerinin aylık gelirine göre anlamlı bir farklılık gösterip göstermediği tek yönlü varyans analizi (ANOVA) ile incelenmiş ve elde edilen bulgular Tablo 12'de verilmiştir. 
Tablo 12: Ailenin Gelirine Göre Faktör Puanlarına İlişkin ANOVA Testi Sonuçları

\begin{tabular}{|c|c|c|c|c|c|c|}
\hline & $\begin{array}{l}\text { Varyans } \\
\text { Kaynağı }\end{array}$ & $\begin{array}{c}\text { Kareler } \\
\text { Toplamı }\end{array}$ & $\begin{array}{c}\text { Serbestlik } \\
\text { Derecesi }\end{array}$ & $\begin{array}{l}\text { Kareler } \\
\text { Ort. }\end{array}$ & $\mathbf{F}$ & $\mathbf{p}$ \\
\hline \multirow{3}{*}{ Marka Algis1 } & $\begin{array}{l}\text { Gruplar } \\
\text { Aras1 }\end{array}$ & 2,966 & 4 &, 741 & \multirow{3}{*}{1,506} & \multirow{3}{*}{,200 } \\
\hline & Gruplar İçi & 171,327 & 348 & ,492 & & \\
\hline & Toplam & 174,292 & 352 & & & \\
\hline \multirow{3}{*}{$\begin{array}{l}\text { Marka } \\
\text { Sadakati }\end{array}$} & $\begin{array}{l}\text { Gruplar } \\
\text { Aras1 }\end{array}$ & 8,689 & 4 & 2,172 & \multirow{3}{*}{2,464} & \multirow{3}{*}{,045 } \\
\hline & Gruplar İçi & 306,834 & 348 &, 882 & & \\
\hline & Toplam & 315,523 & 352 & & & \\
\hline \multirow{3}{*}{$\begin{array}{l}\text { Algilanan } \\
\text { Kalite }\end{array}$} & $\begin{array}{l}\text { Gruplar } \\
\text { Aras1 }\end{array}$ & 3,135 & 4 &, 784 & \multirow{3}{*}{1,152} & \multirow{3}{*}{,332 } \\
\hline & Gruplar İçi & 236,705 & 348 & ,680 & & \\
\hline & Toplam & 239,840 & 352 & & & \\
\hline \multirow{3}{*}{$\begin{array}{l}\text { Marka } \\
\text { Farkındalığı }\end{array}$} & $\begin{array}{l}\text { Gruplar } \\
\text { Aras1 }\end{array}$ & 2,032 & 4 & ,508 & \multirow{3}{*}{0,966} & \multirow{3}{*}{,426 } \\
\hline & Gruplar İçi & 183,038 & 348 & ,526 & & \\
\hline & Toplam & 185,070 & 352 & & & \\
\hline \multirow{3}{*}{ Marka Değeri } & $\begin{array}{l}\text { Gruplar } \\
\text { Aras1 }\end{array}$ & 3,857 & 4 & ,964 & \multirow{3}{*}{1,078} & \multirow{3}{*}{0,367} \\
\hline & Gruplar İçi & 311,394 & 348 & ,895 & & \\
\hline & Toplam & 315,251 & 352 & & & \\
\hline
\end{tabular}

Tablo 12'deki bulgulara göre öğrencilerin bankalarına yönelik genel marka algılarıyla birlikte algılanan kalite, marka farkındalığ 1 ve marka değeri puanları ailelerinin gelirine göre anlamlı bir farklılık göstermemektedir $(p>0,05)$. Marka sadakati puanları ise anlamlı bir farklılık göstermektedir $(\mathrm{p}<0,05)$. Bu farklılığın hangi gruplar arasındaki farklılıktan kaynaklandığını belirlemek amacıyla gruplar arası varyansların homojen olduğu durumda kullanılan çoklu karşılaştırma testlerinden biri olan Tukey çoklu karşılaştırma testi kullanılmıştır. Tukey testi sonucunda bu farklılığın ailesinin geliri $1500 \mathrm{TL}$ altında olan grupla 1501 TL-3000 TL arasında olan grup arasındaki farlılıktan kaynaklandığ 1 belirlenmiş, grup ortalamaları dikkate alındığında ailesinin geliri $1500 \mathrm{TL}$ altında olan öğrencilerin marka sadakatlerinin daha yüksek olduğu belirlenmiştir.

\subsection{Kurumsal Sosyal Sorumluluk Algısı ile Marka Değeri Algısı Arasındaki İlişki}

Bankacılık ve finans bölümü öğrencilerinin müşterisi oldukları bankaya yönelik KSS alg1S1 ve alt boyutları ile marka değeri alg1S1 ve alt boyutları arasında ilişki olup olmadığını incelemek ve eğer mevcutsa bu ilişki veya ilişkilerin yönünü ve şiddetini belirleyebilmek için öncelikle bu 
değişkenler arasındaki Pearson korelasyon katsayısı hesaplanmıştır. Bulgular Tablo 13'teki gibi elde edilmiştir.

Korelasyon katsayısının büyüklük bakımından yorumlanmasında üzerinde tam olarak anlaşılan aralıklar bulunmamakla birlikte genel kabul gören bazı ölçütler mevcuttur. Bunlardan en yaygın kabul görenlerinden biri olan Büyüköztürk (2010)' a göre korelasyon katsayısının mutlak değeri 0,70-1,00 arasında ise yüksek ilişkiyi, 0,30-0,70 arasında ise orta düzey ilişkiyi, 0,00-0,30 arasında ise düşük ilişkiyi gösterir.

Tablo 13: KSS ve Alt Boyutları ile Marka Alg1s1 ve Alt Boyutları Arasındaki Pearson Korelasyon Katsayıları

\begin{tabular}{|c|c|c|c|c|c|}
\hline & $\mathbf{N}$ & Ort. & SS & $\mathbf{r}$ & $\mathbf{p}$ \\
\hline \multirow{2}{*}{$\begin{array}{l}\text { KSS } \\
\text { Marka Alg1S1 }\end{array}$} & 353 & 3,37 & ,62 & \multirow{2}{*}{0,621} & \multirow{2}{*}{$0,000^{*}$} \\
\hline & 353 & 3,29 & ,70 & & \\
\hline \multirow{2}{*}{$\begin{array}{l}\text { KSS } \\
\text { Marka Sadakati }\end{array}$} & 353 & 3,37 & 62 & \multirow{2}{*}{0,491} & \multirow{2}{*}{$0,000^{*}$} \\
\hline & 353 & 3,23 & ,94 & & \\
\hline \multirow{2}{*}{$\begin{array}{l}\text { KSS } \\
\text { Alg1lanan Kalite }\end{array}$} & 353 & 3,37 & 62 & \multirow{2}{*}{0,633} & \multirow{2}{*}{$0,001^{*}$} \\
\hline & 353 & 3,42 & ,83 & & \\
\hline \multirow{2}{*}{$\begin{array}{l}\text { KSS } \\
\text { Marka Farkındalığı }\end{array}$} & 353 & 3,37 & ,62 & \multirow{2}{*}{0,429} & \multirow{2}{*}{$0,000^{*}$} \\
\hline & 353 & 3,17 &, 73 & & \\
\hline \multirow{3}{*}{$\begin{array}{l}\text { KSS } \\
\text { Marka Değeri }\end{array}$} & 353 & 3,37 & ,62 & \multirow{2}{*}{0,463} & \multirow{2}{*}{$0,000^{*}$} \\
\hline & 353 & 3,32 & ,95 & & \\
\hline & $\mathbf{N}$ & Ort. & SS & $\mathbf{r}$ & $\mathbf{p}$ \\
\hline \multirow{2}{*}{$\begin{array}{l}\text { Ticari Sorumluluk } \\
\text { Marka Alg1sı }\end{array}$} & 353 & 3,38 & ,73 & \multirow{2}{*}{0,545} & \multirow{2}{*}{$0,000^{*}$} \\
\hline & 353 & 3,29 &, 70 & & \\
\hline \multirow{2}{*}{$\begin{array}{l}\text { Ticari Sorumluluk } \\
\text { Marka Sadakati }\end{array}$} & 353 & 3,38 & ,73 & \multirow{2}{*}{0,429} & \multirow{2}{*}{$0,000^{*}$} \\
\hline & 353 & 3,23 & ,94 & & \\
\hline \multirow{2}{*}{$\begin{array}{l}\text { Ticari Sorumluluk } \\
\text { Algilanan Kalite }\end{array}$} & 353 & 3,38 & ,73 & \multirow{2}{*}{0,556} & \multirow{2}{*}{$0,000^{*}$} \\
\hline & 353 & 3,42 & 83 & & \\
\hline \multirow{2}{*}{$\begin{array}{l}\text { Ticari Sorumluluk } \\
\text { Marka Farkındalığı }\end{array}$} & 353 & 3,38 &, 73 & \multirow{2}{*}{0,370} & \multirow{2}{*}{$0,000^{*}$} \\
\hline & 353 & 3,17 & ,73 & & \\
\hline \multirow{2}{*}{$\begin{array}{l}\text { Ticari Sorumluluk } \\
\text { Marka Değeri }\end{array}$} & 353 & 3,38 & ,73 & & 0 * \\
\hline & 353 & 3,32 & ,95 & 0,414 & 0,000 \\
\hline & $\mathbf{N}$ & Ort. & SS & $\mathbf{r}$ & $\mathbf{p}$ \\
\hline Etik $\quad$ Sorumluluk & 353 & 3,39 & ,72 & & \\
\hline Marka Algısı & 353 & 3,29 & ,70 & 0,584 & 0,000 \\
\hline Etik $\quad$ Sorumluluk & 353 & 3,39 & ,72 & 0463 & $0000^{*}$ \\
\hline Marka Sadakati & 353 & 3,23 & ,94 & 0,403 & 0,000 \\
\hline Etik $\quad$ Sorumluluk & 353 & 3,39 & ,72 & & * \\
\hline Algilanan Kalite & 353 & 3,42 & ,83 & 0,015 & 0,000 \\
\hline Etik $\quad$ Sorumluluk & 353 & 3,39 & ,72 & & 0 * \\
\hline Marka Farkındalığ1 & 353 & 3,17 & ,73 & 0,395 & 0,000 \\
\hline Etik Sorumluluk & 353 & 3,39 & ,72 & & \\
\hline Marka Değeri & 353 & 3,32 & ,95 & 0,417 & 0,000 \\
\hline & $\mathbf{N}$ & Ort. & SS & $\mathbf{r}$ & $\mathbf{p}$ \\
\hline Sosyal Sorumluluk & 353 & 3,36 & ,66 & & * \\
\hline Marka Alg1sı & 353 & 3,29 &, 70 & 0,548 & 0,000 \\
\hline
\end{tabular}




\begin{tabular}{|c|c|c|c|c|c|}
\hline \multirow{2}{*}{$\begin{array}{l}\text { Sosyal Sorumluluk } \\
\text { Marka Sadakati }\end{array}$} & 353 & 3,36 & 66 & \multirow{2}{*}{0,434} & \multirow{2}{*}{$0,000^{*}$} \\
\hline & 353 & 3,23 & ,94 & & \\
\hline \multirow{2}{*}{$\begin{array}{l}\text { Sosyal Sorumluluk } \\
\text { Algilanan Kalite }\end{array}$} & 353 & 3,36 & ,66 & \multirow{2}{*}{0,536} & \multirow{2}{*}{$0,000^{*}$} \\
\hline & 353 & 3,42 & ,83 & & \\
\hline \multirow{2}{*}{$\begin{array}{l}\text { Sosyal Sorumluluk } \\
\text { Marka Farkındalığı }\end{array}$} & 353 & 3,36 & ,66 & \multirow{2}{*}{0,400} & \multirow{2}{*}{$0,000^{*}$} \\
\hline & 353 & 3,17 & ,73 & & \\
\hline \multirow{2}{*}{$\begin{array}{l}\text { Sosyal Sorumluluk } \\
\text { Marka Değeri }\end{array}$} & 353 & 3,36 & 66 & \multirow{2}{*}{0,417} & \multirow{2}{*}{$0,000^{*}$} \\
\hline & 353 & 3,32 & ,95 & & \\
\hline
\end{tabular}

Tablo 13'teki sonuçlara göre öğrencilerin müşterisi oldukları bankaya yönelik KSS algısı ve alt boyutları ile marka değeri algısı ve alt boyutlarının tamamının arasında pozitif yönlü ve orta düzeyde birer korelasyon ilişkisi olduğu görülmektedir. $(0,3<\mathrm{r}<0,7$; $\mathrm{p}<0,05)$.

$\mathrm{Bu}$ aşamada anlamlı bulunan korelasyon ilişkileri dikkate alınarak öncelikle KSS algısının, marka değeri algısı ve alt boyutlarının birer tahmin edicisi olabileceği düşünülmüş ve bu bağlamda basit doğrusal regresyon analizi yapılmıştır. Regresyon analizinin alternatif hipotezleri şu şekilde oluşturulmuştur:

$\mathbf{H}_{\mathbf{1}}$ : Öğrencilerin bankalarına yönelik KSS algıları arttıkça marka algıları da artmaktadır.

$\mathbf{H}_{1 \mathbf{b}}$ : Öğrencilerin bankalarına yönelik KSS algıları arttıkça marka sadakatleri de artmaktadır.

$\mathbf{H}_{1 \mathbf{c}}$ : Öğrencilerin bankalarına yönelik KSS algıları arttıkça bankalarına yönelik algıladıkları kalite de artmaktadır.

$\mathbf{H}_{1 \mathrm{~d}}$ : Öğrencilerin bankalarına yönelik KSS algıları arttıkça marka farkındalıkları da artmaktadır.

$\mathbf{H}_{1 \mathrm{e}}$ : Öğrencilerin bankalarına yönelik KSS algıları arttıkça bankalarına yönelik algıladıkları marka değeri de artmaktadır.

$\mathrm{Bu}$ kapsamda yapılan beş ayrı regresyon analizinin sonucunda elde edilen bulgular özetle Tablo 14'te verilmiştir.

Tablo 14: Marka Algısının ve Alt Boyutlarının KSS Algısından Etkilenip Etkilenmeme Durumuna Yönelik Regresyon Analizi Sonuçları

\begin{tabular}{|c|c|c|c|c|c|c|c|}
\hline $\begin{array}{l}\text { Bağımlı } \\
\text { Değişken }\end{array}$ & $\begin{array}{l}\text { Bağımsız } \\
\text { Değişken }\end{array}$ & $\boldsymbol{\beta}$ & $\mathbf{t}$ & $\mathbf{p}$ & $\mathbf{F}$ & $\begin{array}{c}\text { Model } \\
\text { (p) }\end{array}$ & $\mathbf{R}^{2}$ \\
\hline \multirow{2}{*}{$\begin{array}{l}\text { Marka } \\
\text { Algis1 }\end{array}$} & Sabit & 0,929 & 5,725 & 0,000 & \multirow{2}{*}{219,77} & \multirow{2}{*}{0,000} & \multirow{2}{*}{0,385} \\
\hline & KSS & 0,700 & 14,825 & 0,000 & & & \\
\hline \multirow{2}{*}{$\begin{array}{l}\text { Marka } \\
\text { Sadakati }\end{array}$} & Sabit & 0,724 & 2,986 & 0,003 & \multirow{2}{*}{111,23} & \multirow{2}{*}{0,000} & \multirow{2}{*}{0,241} \\
\hline & KSS & 0,745 & 10,547 & 0,000 & & & \\
\hline \multirow{2}{*}{$\begin{array}{l}\text { Algilanan } \\
\text { Kalite }\end{array}$} & Sabit & 0,588 & 3,129 & 0,002 & \multirow{2}{*}{234,29} & \multirow{2}{*}{0,000} & \multirow{2}{*}{0,400} \\
\hline & KSS & 0,838 & 15,307 & 0,000 & & & \\
\hline
\end{tabular}




\begin{tabular}{|l|l|l|l|l|l|l|l|}
\hline \multirow{2}{*}{$\begin{array}{l}\text { Marka } \\
\text { Farkındalı̆̆ } 1\end{array}$} & Sabit & 1,488 & 7,728 & 0,000 & \multirow{2}{*}{79,282} & \multirow{2}{*}{0,000} & \multirow{2}{*}{0,184} \\
\cline { 2 - 5 } & KSS & 0,499 & 8,904 & 0,000 & & & \\
\hline \multirow{2}{*}{$\begin{array}{l}\text { Marka } \\
\text { Değeri }\end{array}$} & Sabit & 0,943 & 3,824 & 0,000 & \multirow{2}{*}{95,692} & \multirow{2}{*}{0,000} & 0,214 \\
\cline { 2 - 5 } & KSS & 0,703 & 9,782 & 0,000 & & & \\
\hline
\end{tabular}

Tablo 14'teki bulgulara göre, ilk olarak marka algısının algılanan KSS düzeyinden etkilenme durumunu test etmek için kurulan regresyon modeli istatistiksel olarak anlamlıdır $(\mathrm{F}=219,77 \mathrm{p}<0,05)$. Aynı bulgulara göre $\mathrm{H}_{1 \mathrm{a}}$ hipotezi kabul edilerek öğrencilerin algıladıkları KSS düzeyleri arttıkça marka değeri algılarının da olumlu yönde arttığı söylenebilir $(\beta=0,700 ; \mathrm{t}=14,825 ; \mathrm{p}<0,05)$. Ayrıca KSS algısı, marka algısını yaklaşık $\% 39$ oranında açıklamaktadır $\left(\mathrm{R}^{2}=0,385\right)$.

İkinci olarak marka sadakatinin algılanan KSS düzeyinden etkilenme durumunu test etmek için kurulan regresyon modeli de istatistiksel olarak anlamlıdır $(\mathrm{F}=111,23 ; \mathrm{p}<0,05)$. Bu bulgulara göre $\mathrm{H}_{1 \mathrm{~b}}$ hipotezi kabul edilmektedir. Buna göre öğrencilerin algıladıkları KSS düzeyleri arttıkça marka sadakatleri de olumlu yönde artmaktadır $(\beta=0,745 ; \mathrm{t}=10,547$; $\mathrm{p}<0,05)$. Ayrıca KSS algısı, marka algısını yaklaşık \%24 oranında açıklamaktadır $\left(\mathrm{R}^{2}=0,241\right)$.

Üçüncü olarak algılanan kalitenin algılanan KSS düzeyinden etkilenme durumunu test etmek için kurulan regresyon modeli de yine istatistiksel olarak anlamlidir $(\mathrm{F}=234,29 ; \mathrm{p}<0,05) . \mathrm{H}_{1 \mathrm{c}}$ hipotezi de kabul edilerek öğrencilerin algıladıkları KSS düzeyleri arttıkça algıladıkları kalitenin de olumlu yönde arttı̆̆ı sonucuna varılmıştır $(\beta=0,838 ; \mathrm{t}=15,307 ; \mathrm{p}<0,05)$. Ayrıca KSS algısı, algılanan kaliteyi \%40 oranında açıklamaktadır $\left(\mathrm{R}^{2}\right.$ $=0,400)$.

Dördüncü olarak marka farkındalığının algılanan KSS düzeyinden etkilenme durumunu belirlemek için kurulan regresyon modeli de yine anlamlıdır $(\mathrm{F}=79,282 ; \mathrm{p}<0,05)$. Aynı bulgulara göre $\mathrm{H}_{1 \mathrm{~d}}$ hipotezi kabul edilir ve buna göre öğrencilerin algıladıkları KSS düzeyleri arttıkça marka farkındalıkları da olumlu yönde artmaktadır $(\beta=0,499 ; \mathrm{t}=8,904$; $\mathrm{p}<0,05)$. Ayrıca KSS algısı, marka farkındalığını yaklaşık \%18 oranında açıklamaktadır $\left(\mathrm{R}^{2}=0,184\right)$.

Son olarak ise marka değerinin algılanan KSS düzeyinden etkilenme durumunun tespiti için yapılan regresyon modeli yine istatistiksel olarak anlamlıdır $(\mathrm{F}=95,692 ; \mathrm{p}<0,05)$. Model bulgularına göre $\mathrm{H}_{1 \mathrm{e}}$ hipotezi de kabul edilerek öğrencilerin algıladıkları KSS düzeyleri arttıkça marka değeri algılarının da olumlu yönde arttığ 1 belirlenmiştir $(\beta=0,703$; $\mathrm{t}=9,782 ; \mathrm{p}<0,05)$. Ayrıca KSS algıs1, marka değeri algısını yaklaşık \%21 oranında açıklamaktadır $\left(\mathrm{R}^{2}=0,214\right)$. 


\section{Sonuç}

Bankalar, finansal piyasalarda fon fazlası olandan fon ihtiyac1 olana aracılık eden kurumlardır. Gelişmekte olan ülkelerde finansal piyasaların önemli bir kısmına hâkim olan bankalar ve ekonomiye kattıkları ilave değer önem arz etmektedir. Teknolojik yeniliklerle birlikte bankalarda faaliyetlerinde birtakım düzenlemelere yönelmektedir. Günümüzde diğer işletmeler gibi bankalar da kurumsal sosyal sorumluluk faaliyetlerine ağırlık vermekte ve rekabet üstünlüğü sağlamaya çalışmaktadırlar.

$\mathrm{Bu}$ bağlamda bu çalışma kapsamında öncelikle bankaların müşterileri, ileride ise yönetici ya da çalışanları olmaya aday bankacılık ve finans lisans öğrencilerinin bankaların kurumsal sosyal sorumluluk faaliyetleri hakkında ne ölçüde fikir sahibi oldukları araştırılmıştır.

Araştırma sonuçlarına göre öğrencilerin yaklaşık \%23'ü kurumsal sosyal sorumluluk hakkında bilgi sahibiyken \%77'si bilgi sahibi değildir. Yine öğrencilerin sadece \%11'i bankasının kurumsal sosyal sorumluluk projelerinden haberdar iken \%89'u bu konuda herhangi bir bilgiye sahip değildir. Öğrencilerin bankanın en çok hangi hizmetinden yararlandığına bakılacak olursa yaklaşı \% $\% 2$ 'sinin vadesiz mevduat hesabını, \%26'sının kredi kartı hizmetini, \%14'ünün ise internet-telefon bankacıllı̆g hizmetini en çok kullandıkları görülmektedir. Öğrencilerin çoğunluğu KSS faaliyetlerinden ve bankalarının gerçekleştirmiş olduğu KSS faaliyetlerinden haberdar değildir. $\mathrm{Bu}$ sonuç, bankalar adına hizmet verdikleri öğrencilerin marka sadakati ve diğer marka algisı alt boyutlarını artırmaları için olumsuz bir durumdur.

Ayrıca öğrencilerin algıladıkları kurumsal sosyal sorumluluk puanları ve alt boyutlarının hiçbiri için cinsiyete ve öğrenim gördükleri üniversiteye göre anlamlı bir farklılık tespit edilmemiştir. Yine araştırma bulgularına göre öğrencilerin algıladıkları kurumsal sosyal sorumluluk puanları, etik sorumluluk puanları ve sosyal sorumluluk puanları KSS hakkında bilgi sahibi olup olmadıklarına göre anlamlı bir farklılık göstermezken, ticari sorumluluk puanları anlamlı bir farklılık göstermektedir. KSS hakkında bilgi sahibi olan öğrencilerin bankalarının ticari sorumluluğuna yönelik algılarının daha yüksek olduğu görülmüştür. KSS hakkında bilgi sahibi öğrencilerin bankalarının ticari sorumluluğuna önem veriyor olması ayrıca ilgi çeken bir konudur. Öğrencilerin algıladıkları kurumsal sosyal sorumluluk puanlarının, etik sorumluluk puanlarının, sosyal sorumluluk puanlarının ve ticari sorumluluk puanlarının hiçbirisi öğrencinin ailesinin gelirine göre anlamlı bir farklılık göstermemektedir.

Öğrencilerin genel marka algısı, marka farkındalığı ve marka değeri puanları cinsiyete göre anlamlı bir farklılık göstermezken, marka 
sadakatleri ve algılanan kalite puanları ise anlamlı bir farklılık göstermektedir. $\mathrm{Bu}$ doğrultuda k1z öğrencilerin marka sadakatlerinin ve algılanan kalite puanlarının erkeklere göre daha yüksek olduğu tespit edilmiştir. Ayrıca öğrencilerin bankalarına yönelik marka algılarının ve alt boyut puanlarının tamamının öğrenim gördükleri üniversiteye göre anlamlı bir farklılık göstermediği de görülmüştür.

Yine çalışma bulgularına göre öğrencilerin bankalarına yönelik genel marka algılarıyla birlikte algılanan kalite, marka farkındalığı ve marka değeri puanları ailelerinin gelirine göre anlamlı bir farklılık göstermemektedir. Buna rağmen marka sadakati puanları ise anlamlı bir farkl111k göstermektedir.

Öğrencilerin müşterisi oldukları bankaya yönelik KSS algısı ve alt boyutları ile marka değeri algısı ve alt boyutlarının tamamının arasında pozitif yönlü ve orta düzeyde birer korelasyon ilişkisi olduğu belirlenmiştir. Aynı zamanda yapılan regresyon analizi sonuçlarına göre öğrencilerin algıladıkları KSS düzeyleri arttıkça marka değeri algıları da olumlu yönde artmaktadır. Ayrıca yine regresyon analizi sonuçlarına göre öğrencilerin algıladıkları KSS düzeyleri arttıkça marka sadakatleri, algıladıkları kalite ve marka farkındalıkları da olumlu yönde artmaktadır. $\mathrm{Bu}$ sonuçlara göre KSS faaliyetleri hakkında farkındalığın artırılmasının, marka değeri algısı ve ürün ve hizmet satışlarında artışa etkisi olacağı düşünülmektedir.

Araştırma sonucunda elde edilen bu bulgular literatürde daha önce yapılan benzer konulu çalışmaların bulguları tarafından da desteklenmektedir. Özdemir (2009) çalışmasında işletmelerin KSS faaliyetlerinin marka imajlarını yaratmadaki yerine ve önemine değinmiştir. Akbaş (2010) çalışmasında işletmelerin KSS faaliyetlerinin müşterilerin marka sadakatleri üzerinde olumlu yönde bir etkiye sahip olduğunu ortaya koymuştur. Eren ve Eker (2012) ise çalışmalarında KSS, marka imajı ve algılanan marka değeri değişkenleri arasındaki ilişkiyi incelemişler ve çalışma bulguları sonucunda işletmelerin KSS faaliyetlerinin marka imajı ve müşterilerin algıladıkları marka değeri üzerinde pozitif yönde bir etkiye sahip olduğunu ortaya koymuşlardır. Akkoyunlu ve Kalyoncuoğlu (2014) da araştırmalarında işletmelerin KSS faaliyetlerinin müşterilerin marka farkındalığı, algıladıkları kalite, marka sadakatleri ve marka çağrışımları üzerinde etkili olduğunu ve bu etkinin yönünün pozitif olduğunu tespit etmişlerdir. Son olarak Deneçli (2015) çalışmasında KSS projesi gerçekleştiren bir işletmenin projeden haberdar olan bireyler üzerinde marka farkındalığının daha yüksek olduğunu belirlemiştir. Tüm bu bulgulara paralel olarak, bu çalışmada ise bankaların müşterisi olan üniversite öğrencilerinin algıladıkları KSS 
düzeyinin bankaların genel marka değeri ve marka değerinin alt boyutları olan marka sadakati, marka farkındalığı ve algılanan kalite üzerinde olumlu yönde bir etkiye sahip olduğu ortaya konulmuştur.

Araştırmanın kapsamı ve bulguları doğrultusunda bankalara ve araştırmacılara aşağıdaki noktalar öneri olarak sunulabilir:

- Öncelikle araştırmanın çalışma grubunu sadece Gazi ve Cumhuriyet Üniversitelerinde öğrenim gören öğrenciler oluşturmaktadır ve bu durum araştırmanın bir sınırlılığı olarak değerlendirilebilir. Araştırmacılar farklı üniversitelerdeki öğrencilere de ulaşarak araştırma sonuçlarının tüm üniversite öğrencilerine genelleştirilip genelleştirilmeyeceğini inceleyebilirler.

- Araştırmanın bir diğer sınırlılığı ise çalışma grubunda bankaların sadece üniversite öğrencisi olan müşterilerine yer verilmesidir. Yine araştırmacılar bankaların farklı kesimlerdeki müşterilerini de dikkate alarak araştırma bulgularının genellenebilirliğini sorgulayabilirler.

- Son olarak, araştırma bulgularının bankalar için müşteri odaklı politikalar belirlemede 1şık tutucu bilgiler sunduğu düşünülmektedir. Bu bakımdan bankalar özellikle üniversite öğrencisi olan genç müşterilerine yönelik politikalar geliştirirken araştırma sonuçlarını dikkate alabilirler.

\section{Kaynaklar}

Aaker, David A. (1996). "Measuring Brand Equity Across Products and Markets". California Management Review, 38(3):102-120.

Akbaş, Emel (2010). “Kurumsal Sosyal Sorumluluk Uygulamalarının Tüketici Marka Bağlllı̆̆ına Etkisinin Araştırılması". Yayımlanmamış Yüksek Lisans Tezi. Çanakkale: Çanakkale Onsekiz Mart Üniversitesi Sosyal Bilimler Enstitüsü.

Akkoyunlu, Gonca Şükriye ve Kalyoncuoğlu, Selma (2014). "İşletmelerin Kurumsal Sosyal Sorumluluk Çalışmalarının Marka Alg1sı Üzerine Etkisinin Değerlendirilmesi”. Niğde Üniversitesi İktisadi ve İdari Bilimler Fakültesi Dergisi, 7(3):125-144.

Alparslan, Ajar ve Aygün, Mehmet (2013). "Kurumsal Sosyal Sorumluluk ve Firma Performans1". Süleyman Demirel Üniversitesi İktisadi ve İdari Bilimler Fakültesi Dergisi, 18(1):435448.

Altunoğlu, Ali Ender ve Saraçoğlu, Tuğçe (2013). "Kurumsal Sosyal Sorumluluk Uygulamalarının Müş̧eri Güveni, Müşteri Bağlılığı Ve Firma İmajı Üzerine Etkileri: Otel İşletmelerinde Bir İnceleme”. Sakarya İktisat Dergisi, 2(2):69-89. 
Anbar, Adem; Anbar, Deniz ve Çorak, Sinem (2017). "Üniversite Öğrencilerinin Kurumsal Sosyal Sorumluluk Algilarının Ölçülmesi: Uludağ Üniversitesi İktisadi ve İdari Bilimler Fakültesi Örneği". Yönetim ve Ekonomi Araştırmaları Dergisi, 15(2): 119139.

Büyüköztürk, Şener (2010). Sosyal Bilimler İçin Veri Analizi El Kitabı. 12. Bask1, Ankara: Pegem Akademi.

Can, Emel. (2007). "Marka ve Marka Yapılandırma”. Marmara Üniversitesi IIBFF Dergisi, 22(1):225-237.

Carroll, Achie B. (1979). "A Three-Dimensional Conceptual Model of Corporate Performance", Academy of Management Review, 4(4): 497-505.

Carroll, Achie B. (1991). "The Pyramid of Corporate Social Responsibility: Toward the Moral Management of Organizational Stakeholders". Business Horizons, 34(4): 39-48.

Cingöz, Ayşe ve Akdoğan, Asuman A. (2012). "İşletmelerin Kurumsal Sosyal Sorumluluk Faaliyetleri:Kayseri İli'nde Bir Uygulama", Atatürk Üniversitesi Sosyal Bilimler Enstitüsü Dergisi, 16(3):331349.

Cyr, Dianne; Hassa nein, Khaled; Head, Milena ve Ivanov, Alex (2007). "The role of social presence in establishing loyalty in e-Service environments". Interacting with Computers, 19:43-56.

Çakır, Ahmet ve Arslan, Baran (2016). "Kurumların Uyguladıkları Sosyal Sorumluluk Projelerinin Tüketicilerin Marka Sadakati Üzerine Etkileri: Otomobil Markaları Üzerine Bir Araştırma". CBÜ Sosyal Bilimler Dergisi, 14(2):437-452.

Çetinsöz, Burçin Cevdet ve Artuğer, Savaş (2013). “Antalya İli’nin Marka Değerinin Ölçülmesine Yönelik Bir Araştırma”. Anatolia:Turizm Araştırmaları Dergisi, 24(2):200-210.

Çifci, Sertaç ve Cop, Ruziye (2007). "Marka ve Marka Yönetimi Kavramlar1: Üniversite Öğrencilerinin Kot Pantolon Marka Tercihlerine Yönelik Bir Araştırma”. Finans, Politik \& Ekonomik Yorumlar, 44(512):69-88.

Davis, Keith (1960). "Can business afford to ignore social responsibilities?” California Management Review, 2(3):70-76. 
Deneçli, Sevda (2015). "Kurumsal Sosyal Sorumluluk Projelerinin Marka Farkındalığına Etkisi”. Iletişim Kuram ve Araştırma Dergisi, 40:315-328.

Diken, Ahmet ve Çelebi, Meral Erdiren (2015). Işsletmelerde Işs Ahlakı ve Sosyal Sorumluluk İlişkisi. Değerler Bilançosu Felsese, Sosyoloji, Kamu, Eğitim, Editör: Hasan Hüseyin Bircan ve Bülent Dilmaç, Konya:Çizgi Kitabevi.

Doğru, Sema ve Koçer, Sevim (2016). “GSM Operatörü Kullanıcılarının Marka Sadakati Üzerine Bir İnceleme”. Global Media Journal TR Edition, 6(12):131-171.

Engizek, Nil ve Yaşin, Bahar (2016). "Tüketicilerin Kurumsal Sosyal Sorumluluk Algılamalarının Marka Değeri Üzerine Etkisi”. Anadolu Üniversitesi Sosyal Bilimler Dergisi, 16(2):69:88.

Eren, Selim Said ve Eker, Sevcan (2012). "Kurumsal Sosyal Sorumluluk Algısının Marka İmajı, Algılanan Değer, Müşteri Tatmini Ve Marka Sadakatine Etkisi Üzerine Bir Saha Araştırması: X Markası Örneği". Süleyman Demirel Üniversitesi Iktisadi ve İdari Bilimler Fakültesi Dergisi, 17(2):451:472.

Fahlioğulları, Sinan (2009). The Effects Of Corporate Social Responsibility On Corporate Image, Consumer Trust And Brand Loyalty. Yayınlanmamış Doktora Tezi. İstanbul: Marmara Üniversitesi Sosyal Bilimler Enstitüsü.

Friedman, Milton (1962). Capitalism and Freedom. The University of Chicago Press.

Gil, R. Bravo; Andres, E.Fraj ve Salinas, E. Martinez (2007). "Family As A Source Of Consumer-Based Brand Equity". Journal Of Product \& Brand Management, 16(3):188-199.

Gonzalez-Rodriguez, Maria del Rosairo, Diaz-Fernandez, Maria Carmen, Pawlak, Marek ve Simonetti, Biagio (2013). "Perceptions of Students University of Corporate Social Responsibility". Quality and Quantity, 47(4):2361-2377.

Ilgaz, Hale (2015). “Ergenler İçin Oyun Bağımlılığı Ölçeğinin Türkçe’ye Uyarlama Çalışması". Elementary Education Online, 14(2):874884.

Jones,Peter; Comfort, Daphne ve Hillier, David (2007). "Marketing and corporate social responsibility within food stores". British Food Journal, 109(8):582-593. 
Karagöz, Yalçın (2016). SPSS ve AMOS 23 Uygulamalı Istatistiksel Analizler, 1. Basım, Ankara: Nobel Yayıncılık.

Keller, Kevin Lane (1993). "Conceptualizing, Measuring, and Managing Customer-Based Brand Equity”. Journal of Marketing, 57(1):1-22.

Keller, Kevin Lane (2013). Strategic Brand Management Building, Measuring and Managing Brand Equity. Pearson Education, 4th Edition.

Kim, Hong-Bumm; Kim, Woo Gon ve An, A. Jeong (2003). "The Effect of Consumer-Based Brand Equity on Firms' Financial Performance", Journal of Consumer Marketing, 20(4):35-351.

Kim, Kyung Hoon; Kim, Kang Sik; Kim, Dong Yul; Kim, Jong Ho ve Kang, Suk Hou (2008). "Brand Equity in Hospital Marketing". Journal of Business Research, 61(1):75-82.

Lamsa, Anna-Maija; Vehkapera, Meri; Puttonen, Tuomas ve Pesonen, Hanna-Leena (2008). "Effect of Business Education on Women and Men Students' Attitudes on Corporate Responsibility in Society". Journal of Business Ethics, 82:45-58.

Moon, Jeremy (2007). "The Contribution of Corporate Social Responsibility To Sustainable Development", Sustainable Development, 15(5):296-306.

Özdemir, Hilal (2009). "Kurumsal Sosyal Sorumluluğun Marka İmajına Etkisi”. İstanbul Ticaret Üniversitesi Sosyal Bilimler Dergisi, 8(15):57-72.

Pala, Fahrettin (2017). "Marka Kent Unsurlarından Yerel Markalı Ürünlerde Marka Değerini Etkileyen Faktörler: Gümüşhane İli Örneği”. Uluslararası Bilimsel Araştırmalar Dergisi, 2(8):96-109.

Schwartz, Mark S. ve Carroll, Archie B. (2003). "Corporate Social Responsibility: A Three-Domain Approach". Business Ethichs Quarterly, 13(4):503-530.

Singh, Jaywant,; Sanchez, Maria del Mar Garcia de los Salmones ve Bosque, Ignacio Rodriguez del (2008). "Understanding Corporate Social Responsibility and product perceptions in consumer markets: A cross-cultural evaluation". Journal of Business Ethics, 80(3):597-611.

Söylemez, Cevat ve Kayabaşı, Aydın (2017). "Müşteri Sadakati ve Kurumsal Sosyal Sorumluluk Faaliyetleri (KSS): Kurumsal İmajın 
Aracilık Etkisinin İncelenmesi”. Uluslararası İktisadi ve İdari Incelemeler Dergisi, 16.UİK Özel Sayısı:349-364.

Tosun, Nurhan Babür ve Elmasoğlu, Kamile (2015). "Duyusal Markalamanın Marka Sadakati Üzerindeki Rolü". Maltepe Üniversitesi Illetişim Fakültesi Dergisi, 2(1):91-111.

Tuzcu, Arcan (2014). "The Impact of Corporate Social Responsibility Perception on The Job Satisfaction and Organizational Commitment". Çankır Karatekin Üniversitesi İktisadi ve İdari Bilimler Fakültesi Dergisi, 4(1):185-202.

Türker, Gülay Özaltın ve Türker, Ali (2013). “GSM Operatörleri Sektöründe Marka Sadakatini Etkileyen Faktörlerin Belirlenmesi; Üniversite Öğrencileri Üzerine Bir Uygulama”. Electronic Journal of Vocational Colleges, 3(1):49-67.

Weber, Paula Schmidt; Weber, James E.; Sleeper, Bradley J. ve Schneider, Ken C. (2004). "Self-Efficacy toward Service, Civic Participation and the Business Student: Scale Development and Validation". Journal of Business Ethics, 49(4): 359-369.

Yazgan, H.İbrahim; Kethüda, Önder ve Çat1, Kahraman (2014). "Tüketici Temelli Marka Değerinin Ağızdan Ağza Pazarlamaya Etkisi”. Cumhuriyet Üniversitesi İktisadi ve İdari Bilimler Dergisi, 15(1):237-252.

Yoo, Boonghee ve Donthu, Naveen (2002). "Testing cross-cultural invariance of the brand equity creation process". Journal of Product \& Brand Management, 11(6), 380-98. 